\title{
Metriocnemus van der Wulp : Seven new species, revision of species, and new records (Diptera : Chironomidae)
}

\author{
O. A. Sæther 1
}

Keywords : Diptera, Chironomidae, systematics, Metriocnemus van der Wulp, keys, new species, type revisions.

The congenerity of Arctomyia Lundström, 1915, with Metriocnemus van der Wulp, 1874, is confirmed. Types of Arctomyia sibirica Lundström ; Chironomus picipes Meigen, 1818 : Metriocnemus longipalpus Sinharay et Chaudhuri, 1978 ; and Apometriocnemus beringiensis Cranston et Oliver, 1988 ; are examined.

Metriocnemus sibiricus is close to $M$. longipennis (Holmgren), $M$. picipes is separate from $M$. atriclava Kieffer, $M$. longipalpus is a junior synonym of $M$. picipes, and $M$. beringiensis is close to $M$. fuscipes (Meigen). M. obscuripes (Holmgren) is a junior homonym and replaced by $M$. eurynotus (Holmgren).

Metriocnemus wangi sp. n., $M$. acutus sp. n., $M$. dentipalpus sp. n., M. calvescens sp. n., $M$. sibiricus, $M$. caudigus sp. n., $M$. intergerivus sp. n., $M$. aculeatus Chaudhüi et Bhattacharyay, $M$. unilinearis Chaudhuri et Bhattacharyay, $M$. exilacies sp. n., $M$. beringiensis and $M$. picipes are described as male imagines. The females of $M$. longipennis, $M$ sibiricus, $M$. intergerivus, $M$. picipes and $M$. atriclava are described. Keys to both sexes are presented.

New records from Norway and China are given for $M$. eurynotus, $M$. brusti Sæther, $M$. ursinus (Holmgren), M. fuscipes, $M$. aculeatus, $M$. unilinearis, $M$. beringiensis, and $M$. picipes.

Metriocnemus van der Wulp : sept espèces nouvelles, révision des espèces et nouvelles récoltes (Diptera : Chironomidae) Mots clés : Diptera, Chironomidae, taxonomie, Metriocnemus van der Wulp, clés, nouvelles espèces, révisions de type.

La synonymie de Arctomyia Lundström, 1915, avec Metriocnemus van der Wulp 1874 est confirmée. Les types de Arctomyia sibirica Lundström, Chironomus picipes Meigen, 1818, Metriocnemus longipalpus Sinharay et Chaudhuri, 1978, et Apometriocnemus beringiensis Cranston et Oliver, 1988, sont examinés.

Metriocnemus sibericus est proche de $M$. longipennis (Holmgren), M. picipes est séparé de $M$. atriclava Kieffer, $M$. longipalpus est un junior synonyme de $M$. picipes et $M$. beringiensis est proche de $M$. fuscipes (Meigen). $M$. obscuripes est un junior synonyme et remplacé par $M$. eurynotus (Holmgren).

Les images mâles de Metriocnemus wangi $\mathrm{n}$. sp., $M$. acutus n. sp., $M$. dentipalpus n. sp., $M$. calvescens $\mathrm{n}$. sp., $M$. sibericus, $M$. caudigus n. sp., $M$. intergevirus n. sp., $M$. aculeatus Chaudhuri et Bhattacharyay, $M$. unilinearis Chaudhuri et Bhattacharyay, $M$. exilaxies n. sp., $M$. beringiensis et $M$. picipes sont décrits. Les femelles de $M$. longipennis, $M$. sibericus, $M$. intergerivus, $M$. picipes et $M$. atriclava sont décrites. Des clés des deux sexes sont présentées.

De nouvelles récoltes de Norvège et Chine sont données pour $M$. eurynotus, $M$. brusti Sæther, $M$. ursinus (Holgrem), $M$. fuscipes, $M$. aculeatus, $M$. unilinearis, $M$. beringiensis et $M$. picipes.

\section{Introduction}

The genus Metriocnemus van der Wulp occurs in biotopes ranging from mosses and higher vegetation, pitcher plants and hollow trees to margins of springs, ditches, streams, damp soils and

1. Department of Systematic Zoology, Museum of Zoology, Jniversity of Bergen, N-5007 Bergen, Norway. hygropetric biotopes, and occasionally in lakes and rock pools (Cranston \& Judd 1987, Sæther 1989a).

A substantial number of species have been described in Metriocnemus, but many have been allocated to the genus solely based upon having « hairy » wings and simple male gonostyli. Thus a reexamination of types and other material has been necessary. The more important types, including that of the type species for the genus, $M$. albolineatus (Meigen), were examined and redescribed by Sæther 
(1989a). However, that study raised two unanswered questions concerning the status of Arctomyia sibirica Lundström, 1915, and whether $M$. picipes (Meigen, 1818) was conspecific with $M$. atriclava Kieffer, 1921 sensu Edwards, 1929. In this paper the types of $M$. sibirica and $M$. picipes are examined and redescribed. $M$. longipalpus Sinharay et Chaudhuri, 1978 , is shown to be a junior synonym of $M$. picipes.

In part based upon material from the collection of Kaare Aagaard, Norwegian Institute for Nature research, Trondheim, Apometriocnemus beringiensis Cranston et Oliver $(1988: 428)$ was shown to belong in Metriocnemus (Cranston, Oliver \& Sæther 1989a : 178, 213). The type of $M$. beringiensis is redescribed here together with additional specimens from Norway. The collection of Kaare Aagaard also contained three new species of Metriocnemus and several new records. Xinhua Wang, Nankai University, Tianjin, China, gave me material of Metriocnemus from China to describe. It contained three new species and several new records. In light trap material from Lake Winnipeg, Manitoba, Canada, one new species of Metriocnemus was present.

This is the second in a series of paper revising types and describing new species of the genus Metriocnemus. What remains is a reexamination primarily of Afrotropical and some other type material and an attempt at a phylogenetic treatment. However, the so far unexamined species are described in sufficient detail to allow for a possible placement and inclusion of some of them in the key presented in this paper.

\section{Methods and terminology}

All the material was mounted on slides following the procedure outlined by Sæther $(1969 ; 1)$.

The general terminology follows Sæther (1980) with the additions and corrections given in Sæther (1989a). The counts of setae on the wing veins include both dorsal and ventral setae, setae which stand at the margin of a vein are regarded as belonging to the vein.

In the figures of the male genitalia the dorsal view is shown to the left, the ventral aspect and the apodemes to the right. The measurements are given as ranges followed by a mean when four or more measurements are made, followed by the numbers in parentheses (n). (In the figures of the lobes of gonapophysis VIII in Sæether (1989, p. 414, Fig. 8C, 8D) the lettering of the dorsomesal and ventrolateral lobes are switched. The dorsomesal lobes are lettered VIL, the ventrolateral lobes DmL).

The types examined are from the Meigen collection, Museum National d'Histoire Naturelle, Paris, France (MNHN) ; the Lundström collection, Zoological Institute, St. Petersburg, Russia (ZIS) ; the Canadian National Collection, Ottawa, Canada (CNC), and the collection of the Museum of Zoology, Bergen, Norway (ZMB). Other material belongs to the collections of Kaare Aagaard (KA), Xinhua Wang (XW), and the Freshwater Institute, Winnipeg, Canada (FWI).

\section{Metriocnemus van der Wulp}

\author{
Metriocnemus van der Wulp, $1874: 136$ \\ Wulpiella Kieffer, $1899: 66$ \\ Arctomyia Lundström, 1915 : 18 \\ Dolichoprymna Lundström, 1915 : 21 \\ Gripekovenia Kieffer, 1918 : 134, nomen dubium \\ Chasmatocladius Kieffer in Kieffer \& Thiene- \\ mann, $1919: 47$.
}

Type species : Chironomus albolineatus Meigen, $1818: 39$.

\section{Nomenclatorial notes}

According to Sæther (1989a) all the generic synonyms with the possible exception of Arctomyia belong to the eurynotus (as obscuripes) group. Arctomyia sibirica is here shown to be closely related to $M$. longipennis and thus also a member of the $M$. eurynotus group. Should a subgeneric division of the genus be deemed desirable there thus is no available name for the fuscipes group.

\section{Diagnosis}

As in Coffman et al. (1986:186) and Cranston \& Judd (1987) for the pupa ; and Cranston \& Judd (1987) for the larva. The diagnosis in Sæther (1989a) for the imagines can be emended as follows :

Female antenna with 5 flagellomeres or occasionally 4 flagellomeres in species with reduced wings and reduced male antenna. Third palpal segment with 1-7 lanceolate sensilla clavata at apex, occasionally with an apical spiniform seta or with a small, sclerotized apical tooth. First axillary sclerite with setae. Male anal point occasionally absent. More or less sclerotized plate present basally between 
gonocoxites. Female tergite IX undivided or occasionally with two large, parallelsided, setose posterolateral projections.

\subsection{Systematics}

Sæther (1977: 81-82) placed Metriocnemus together with Thienemannia Kieffer at the base (fig. 36) of the Metriocnemini sensu Sæther (1977). Sæther \& Sublette $(1983: 4)$ showed that the Pseudorthocladius group apparently formed the sister group of the Metriocnemus group. However, this placement could not be confirmed by any method of quantitative phyletics (Sæthèr 1989b, figs 8-10). Apparently the most realistic evaluation (Sæther 1989b, Fig. 10) gave Metriocnemus as one of the most plesiomorphic genera of the Orthocladiinae.

The genus Metriocnemus is quite homogeneous in the adult and pupal stages. The female genitalia, especially the shape of tergite IX, however, is quite variable. This tergite ranges in shape from large and sharply triangular to rounded ; completely undivided, with indication of division or consisting of two large caudolateral projections. The range of variation in larval characters is high. However, the shape and placement of the labral lamellae ; and the sclerotized normally well developed procercus with the short anal setae make the genus easily recognizable.

The genus has been divided into two main groups, the eurynotus (= obscuripes = hygropetricus) group and the fuscipes group. As presently defined all males of the eurynotus group possess well developed virga consisting of a cluster of 6-14 distinct spines, while the virga is lacking in the fuscipes group. However, one of the new species, $M$. intergerivus, possesses relatively short virgal spines, but otherwise resembles the fuscipes group. In $M$. aculeatus Chaudhuri et Bhattacharyay the virgal spines are not clustered, but separate and parallel and unlike other members of the group the crista dorsalis is vestigial. $M$. yaquina Cranston et Judd lacks virgal spines as in the fuscipes group, but has a weak, rounded, preapical crista dorsalis and no apical hump on the inferior volsella, i.e. more like some members of the eurynotus group. Also $M$. caudigus sp. n., $M$. aculeatus, M. longipennis (Holmgren) and $M$. sibiricus (Lundström) are intermediate since they have a long and low crista dorsalis as in the fuscipes group or a long crista dorsalis with a large median projection (in $M$. sibiricus). In the other species of the eurynotus group the crista dorsalis is small, preapcical and triangular to rounded. In M. eurynotus, $M$. ursinus (Holmgren), $M$. calvescens sp. n. and $M$. acutus sp. n. the crista dorsalis is sharply pointed.

In the eurynotus group (excluding $M$. intergerivus sp. n.) there are two main types of inferior volsellae. $M$. martini Thienemann, $M$. edwardsi Jones, M. tamaokui Sasa, $M$. toganiger (Sasa et Okazawa) and $M$. virgatus Sublette et Sasa have a strongly projecting, rectangular basal volsella occupying less than basal half. In the other species the volsella is less projecting, but occupies the basal $0.58-0.80$ of the gonocoxite. It is widest in the basal half and slightly wider in $M$. eurynotus (Holmgren), $M$. brusti Sæther, $M$. dentipalpus sp. n., M. togaminor Sasa et Okazawa and $M$. acutus sp. $\mathrm{n}$. than in the remaining species. The anal point in the eurynotus group is generally strong, $30-70 \mu \mathrm{m}$ long, parallel-sided or tapering to a usually blunt apex, but is lacking in $M$. toganiger, $M$. togaminor and $M$. virgatus Sublette et Sasa.

The male imagines of the fuscipes group (exclu$\operatorname{ding} M$. yaquina, M. unilinearis Chaudhuri et Bhattacharyay, $M$. costatus Sublette et Sasa and $M$. lautus Sublette et Sasa) are quite similar to each other. The inferior volsella occupies basal 0.73-0.89 of the gonocoxite, but is low and weakly developed with an apical hump making the volsellae widest near apex. The crista dorsalis is long and low. The anal point is weak, $0-56 \mu \mathrm{m}$ long, and usually tapers to a sharply pointed apex. but may have a parallelsided apex (in $M$. exilacies sp. n.).

Among the species not yet examined $M$. tristellus Edwards (Edwards 1929 : 312, fig. 3b ; Pinder 1978, fig. 132c) appears to belong in the fuscipes group, however, apparently lacking the apical hump of the inferior volsella. The Japanese species $M$. tamaokui Sasa, $M$. shouclarus Sasa, $M$. amanianomalis Sasa, $M$. togapullus, $M$. togaminor and $M$. toganiger are included in the key below. The first species is close to $M$. martinii, the next three belong in the fuscipes group, while the last two are close to $M$. virgatus in the eurynotus group. $M$. ryutanus Sasa et Hasegawa (1988) clearly is a Paraphaenocladius Thienemann. $P$. ryutanus comb. n. probably is a synonym of $P$. exagitans (Johannsen). The African species $\boldsymbol{M}$. canus Freeman, $\boldsymbol{M}$. conicus Freeman, $M$. lobeliae Freeman, and $M$. wittei Freeman (Freeman $1956: 295-298$ ) apparently all belong in the 
fuscipes group. $M$. canus may be a synonym of $M$. fuscipes (Meigen), $M$. lobeliae a synonym of $M$. atriclava and $M$. wittei a synonym of $M$. picipes.

According to Sinharay \& Chaudhuri (1978:28) and Chaudhuri et al. $(1989: 308)$ there are eight valid Oriental species. However, $M$. discretus Johannsen belongs in Paraphaenocladius judged on the description of the hypopygium and the wing by Johannsen (1932: 717), while $M$. nigrescens Johannsen is probably a Parametriocnemus Goetghebuer. M. longipalpus Sinharay et Chaudhuri is shown here to be a junior synonyum of $M$. picipes. The type of $M$. callinotus Kieffer is fragmentary and the name should be regarded as a nomen dubium. The species erected by Chaudhuri et al. (1989) are included in the key below. However, what is named the virga in $M$. amplispinus Chaudhuri et Bhattacharyay is part of the sclerotized basal connection or plate between gonocoxites apparent in probably all species of Metriocnemus. There are also discrepancies between the description of this species and the drawings of the species. According to the descriptions vein $M$ is bare and tergite IX has 62-65 setae, while according to the drawing there are 12 setae on $M$ and much less than 60 setae on tergite IX. The species is very close to $M$. picipes and, if there are more errors in their counts, could be a junior synonym of $M$. picipes. In $M$. pseudorostratus Chaudhuri et Bhattacharyay the virga is said to be single lobed. If that is the case the species is unlikely to be a Metriocnemus. However, with insufficient clearing the tight cluster of spines may look like a single lobe.

Of the species mentioned by Edwards (1931) from South America as belonging to Metriocnemus only $M$. griseovittatus Edwards is likely to belong to that genus.

Sublette \& Sasa (1994) describe three new species of Metriocnemus from Guatemala. Of these $M$. virgatus Sublette et Sasa is a typical member of the eurynotus group. $M$. costatus Sublette et Sasa and $M$. lautus Sublette et Sasa both are said to lack virgal spines as in the fuscipes group. However, both the pupa and the larva of $M$. costatus are typical of the eurynotus group and the genitalia of both species are more similar to those of members of the eurynotus group. Most likely the virga (which in some species is quite transparent), at least of $M$. costatus, has been overlooked. The male imagines of the three species from Guatemala are included in the key below. Unfortunately, Sublette \& Sasa overlooked Sæther (1989) and thus their descriptions are too incomplete to allow the inclusion of the female imagines in the key.

Among unexamined Nearctic species (Oliver, Dillon \& Cranston 1989 : 30) M. equalis Johannsen (Sublette 1967 : 535) should be placed as Heterotrissocladius equalis (Johannsen) comb. $n$. since the costa is not produced, the wing membrane haired only in the apical fourth, and the shape of the hypopygium conforms to Heterotrissocladius Spärck and not to Metriocnemus. It may be a senior synonym of $H$. changi Sæther or $H$. hirtapex Sather. M. polaris Kieffer (1926:87) was redescribed by Sæther, Sublette \& Willassen (1984: 266) who suggested that it might be a junior synonym of $M$. eurynotus (as obcuripes). This synonymity can now be confirmed.

3.2. Key to sufficiently known male imagines of Metriocnemus van der Wulp

1. Basal half of wing membrane bare or at most with scattered setae in anal cell ............. 2 Entire wing membrane, except sometimes cell $\mathrm{m}$ basally of RM, densely clothed with setae ... 5

2. Anal point weak, tapering to a point, a few setae present in anal cell of wing; crista dorsalis low or absent $\ldots \ldots \ldots \ldots \ldots \ldots \ldots \ldots \ldots \ldots \ldots \ldots$ Anal point robust, rounded apically ; basal half of wing membrane bare ; crista dorsalis triangular, pointed $\ldots \ldots \ldots \ldots \ldots \ldots \ldots \ldots \ldots \ldots$

3. Inferior volsella very low (Edwards 1929, Fig. 3b ; Pinder 1978, Fig. 132c); Holarctic ........... ................ tristellus Edwards Inferior volsella distinct (Chaudhuri et al. 1989, Fig. 1d ; Fig. 7A) ; India, China . . . . . . . . . . . .....M. aculeatus Chaudhuri et Bhattacharyay

4. Squama with $60-73$ setae, cell $\mathrm{r}_{4+5}$ with $112-120$ setae (Pinder 1978, Fig. 132D ; Sæther 1989a, Fig. 11) ; Palaearctic ............. ursinus (Holmgren) Squama with about 27 setae, cell $r_{4+5}$ with about 27 setae (Fig. 1 E) ; China . M. calvescens sp. $n$.

5. Antenna with 12-13 flagellomeres and AR of 0.1-0.3, squama with $5-12$ setae $\ldots \ldots \ldots \ldots \ldots \ldots 6$ When antenna with 12-13 flagellomeres AR higher than 0.4 or antennal plume reduced, squama usually with more than 12 setae . . . . . . . . . 8

6. Anal point absent, 12 flagellomeres or when 13 AR 0.13-0.15, squama with about $5-8$ setae $\ldots \ldots 7$ 
Anal point present, AR about 0.3, squama with about 12 setae (Sasa 1989, Fig. 19) ; Japan ......... M. shouclarus Sasa

7. Third palpomere with apical spiniform seta, 12 flagellomeres, AR 0.3 (Sublette \& Sasa 1994, Figs 103-105) ; Guatemala

M. lautus Sublette et Sasa Third palpomere without spiniform seta, 13 flagellomeres, AR 0.13-0.15 (Sasa 1990, Fig. 18); Japan ......... M. amamianomalus Sasa

8. Virga consisting of 6-14 spines; crista dorsalis preapical and triangular or occasionally long and low or gonostylus with strong preapical projection ....9 Virga absent (possibly present but overlooked in M. costatus Sublette et Sasa, with $\mathrm{LR}_{1}$ of 0.82-0.86, well developed inferior volsella, and 21-34 setae on squama) ; crista dorsalis long and low or, when rounded and preapical, antenna with 7 flagellomeres $\ldots \ldots \ldots \ldots \ldots \ldots \ldots \ldots \ldots \ldots$

9. Wings shortened, antennal plume reduced .... 10 Wings normal, antennal plume well developed 11

10. Antenna with 7 flagellomeres, crista dorsalis long and low (Sæether 1989a, Fig. 13); Holarctic ........ .............. longipennis (Holmgren) Antenna with 12-13 flagellomeres, gonostylus with large median projection (Fig. 4) ; Siberia ....... ................ sibiricus (Lundström)

11. Anal point absent $\ldots \ldots \ldots \ldots \ldots \ldots \ldots \ldots 12$ Anal point present $\ldots \ldots \ldots \ldots \ldots \ldots 14$

12. Inferior volsella in basal half of gonocoxite, strongly projecting, rectangular ............ 13 Inferior volsella in basal $3 / 4$ of gonocoxite, relatively low (Sasa \& Okazawa 1992, Fig. 52), Japan ..... ........... togaminor Sasa et Okazawa

13. AR 0.7-0.9, 59-70 dorsocentrals (Sublette \& Sasa 1994, Figs 106, 107); Guatemala . . . . . . . . . . . . $\ldots \ldots \ldots \ldots \ldots$. virgatus Sublette et Sasa AR 1.2-1.7, 30-46 dorsocentrals (Sasa \& Okazawa 1992, Fig. 48 as Gymnometriocnemus toganiger) . ......M. toganiger (Sasa et Okazawa) comb. n.

14. Crista dorsalis long and low .......... 15 Crista dorsalis preapical, triangular, pointed to rounded $\ldots \ldots \ldots \ldots \ldots \ldots \ldots \ldots \ldots \ldots \ldots \ldots \ldots \ldots$

15. Anal point robust, rounded at apex, 49-68 $\mu \mathrm{m}$ long ; AR about 1,3 ; squama with 18-23 setae (Fig. 5 A) ; Norway . .............. caudigus sp. n. Anal point weak, pointed, $15-26 \mu \mathrm{m}$ long ; AR 2.0-2.4 ; squama with 43-64 setae (Fig. 5 B) ; Holarctic ............. intergerivus sp. $n$.

16. Inferior volsella in basal half of gonocoxite, strongly projecting, rectangular ........... 17 Inferior volsella in basal $0.58-0.80$ of gonocoxite, widest in basal half, weak to pronounced .... 19
17. AR 1.7-1.8, anal point more than half as long as gonostylus (Sublette 1966, Fig. 11); Nearctic .... $M$. edwardsi Jones AR about 0.8-1.2, anal point less than half as long as gonostylus $\ldots \ldots \ldots \ldots \ldots \ldots \ldots \ldots \ldots$

18. Anal point robust, partly parallel-sided with rounded apex (Sasa 1983, Figs 26B-D, 27); Japan ...... ..................... tamaokui Sasa Anal point tapering to point (Pinder 1978, Fig. 130c, as $M$. cavicola Kieffer; Chaudhuri et al. 1989, Fig. 3) ..... M. martini Thienemann (Palaeartic) and $M$. pseudostratus Chaudhuri et Bhattacharyay (India, possible synonym)

19. Subcosta with 0.8 setae, cell $m$ basally of $R M$ with $0-29$ setae .................... 20 Subcosta with 10-55 setae, cell $\mathrm{m}$ basally of RM with

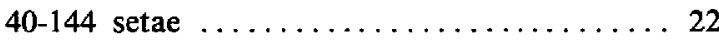

20. AR about 2.2, crista dorsalis sharply pointed (Fig. 1 B) ; Norway ............... acutus sp. n. AR 1.4-1.7, crista dorsalis rounded to bluntly trian-

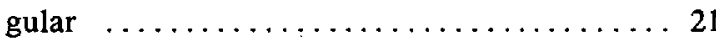

21. Cell $m$ with about 1 seta, squama with about 13 setae, crista dorsalis rounded (Sæther 1989a, Fig. 4) ; Germany ............. Cell $\mathrm{m}$ with 7-29 setae, squama with 27-34 setae, crista dorsalis bluntly triangular ........... 22

22. Vein $M$ with 0-11 setae ; third and fourth palpomere without small, sclerotized apical tooth; anal point triangular (Sæther 1989, Fig. 5) ; Holarctic ..... $M$, brusti Sæether Vein $\mathrm{M}$ with about 20 setae ; third and fourth palpomere each with small, sclerotized apical tooth ; anal point with concave margins (Fig. 1 C, D) ; China $\ldots \ldots \ldots \ldots \ldots \ldots . \ldots \ldots$. dentipalpus sp. $\mathrm{n}$.

23. Spines of virga $23-26 \mu \mathrm{m}$ long, crista dorsalis rounded to bluntly triangular . . . . . . . . 24 Spines of virga 34-68 $\mu \mathrm{m}$ long, crista dorsalis either sharply triangular or rounded .........25

24. AR 0.5-0.6, anal point $24-28 \mu \mathrm{m}$ long (Fig. 1 A) China .................. wangi sp. n. AR 1.2-1.5, anal point 51-64 $\mu$ m long (Sæether 1989a, Fig. 1) ; Palaearctic ....M. albolineatus Meigen

25. AR 1.4-2.1 ; crista dorsalis usually sharply, occasionally bluntly triangular ; anal point variable; but usually robust and parallel-sided (Sæther 1989a, Fig. 7, as $M$. obscuripes) ; Holarctic ........... $\ldots \ldots \ldots \ldots \ldots$. eurynotus (Holmgren) AR. 1.0-1.1 (1.55 in Sublette 1966) ; crista dorsalis rounded, anal point tapering to blunt apex (Sublette 1966, Fig. 12) ; Neartic ..... M. knabi Coquillet

26. Antenna with 7 flagellomeres, front tibia without spur (Cranston \& Judd 1987, Figs 1-2); Neartic . . . . . $\ldots \ldots \ldots \ldots \ldots \ldots$. yaquina Cranston et Judd Antenna with 13 flagellomeres, front tibia with spur ...................... 27 
27. Anal point parallel-sided in apical half ; $M$ with $0-3$ setae, subcosta with 23-40 setae (Fig. 6 C) ; Norway $M$. exilacies sp. $n$. Anal point tapering to pointed apex; when $M$ with less than 10 setae, subcosta also with less than 10 setae ..................... 28

28. $\mathrm{LR}_{1}$ about $0.82-0.87, \mathrm{LR}_{3}$ about $0.51-0.55$, squama with about 7 or with $21-34$ setae ........ 29 $L_{1} \quad 0.52-0.67, L_{3} \quad 0.36-0.46$, squama with $18-58$ setae $\ldots \ldots \ldots \ldots \ldots \ldots \ldots \ldots \ldots \ldots .30$

29. Squama with 7 setae, $L_{1}$ 0.86-0.87 (Chaudhuri et al. 1989, Fig. 4 ; Fig. 6 B) ; India, Tibet ....... ....M. unilinearis Chaudhuri et Bhattacharyay Squama with 21-34 setae, $L_{1}$ 0.82-0.86 (Sublette \& Sasa 1994, Figs 88-90) ; Guatemala

................ costatus Sublette et Sasa

30. AR $0.8-1.2, L_{3} \mathbf{0 . 3 6 - 0 . 4 1}$, pseudospurs often absent on $\operatorname{ta}_{2}$ of hind leg $\ldots \ldots \ldots \ldots \ldots \ldots \ldots \ldots \ldots$ AR 1.5-3.0, $\mathrm{LR}_{3}$ 0.43-0.46, pseudospurs always present on $\mathrm{ta}_{2}$ of hind leg ............... 32

31. Anal point absent or at most $15 \mu \mathrm{m}$ long, wing length 1.5-1.7 mm, squama with $18-26$ setae (Cranston \& Oliver 1988, Fig. 2, as Apometriocnemus beringiensis ; Fig. $6 \mathrm{D}, \mathrm{E})$; Holarctic

$\ldots \ldots \ldots$. beringiensis (Cranston et Oliver) Anal point $23-53 \mu \mathrm{m}$ long, wing length 1.8-2.5 $\mu \mathrm{m}$, squama with 28-40 setae (Sæther 1989a, Fig. 14); Holarctic, including Madeira, the Canary Islands and the Azores ............ M. fuscipes (Meigen)

32. AR 1.8(?)-3.0, subcosta and $M$ each with less than 13 setae, spur of front tibia $\mathbf{2 . 0 - 2 . 7}$ times as long as apical width of tibia $\ldots \ldots \ldots \ldots \ldots \ldots . \ldots 33$ AR 1.5-1.6, subcosta with 36-39 setae, $M$ with 23-39 setae, spur of front tibia about 1.6 times as long as apical width of tibia (Sæther 1989a, Fig. 16); Palaearctic ............... atriclava Kieffer

33. Anal point absent, squama with $28-42$ setae (Sasa \& Okazawa 1992, Fig. 53) ; Japan ............ ............M. togapullus Sasa et Okazawa Anal point present, squama either with $22-23$ or $42-58$ setae ....................... 34

34. Squama with 22-23 setae, tergite IX with $62-65$ setae, only about 12 temporals (Chaudhuri et al. 1989, Fig. 2) ; India

....M. amplispinus Chaudhuri et Bhattacharyay Squama with 42-58 setae, tergite IX with 30-40 setae, 23-25 temporals (Fig. 7 A) ; Holarctic and Oriental

M. picipes (Meigen)

\subsection{Key to some female imagines of Metriocnemus van der Wulp}

1. Squama with 3-10 setae, legs robust with spur of front tibia shorter than apical width of tibia and BR of all legs lower than 2.3
Squama with 13-73 setae except for 4-7 setae in $M$. unilinearis, legs more slender with spur of front tibia longer than apical width of tibia and BR at least of hind leg higher than $2.2 \ldots \ldots \ldots \ldots \ldots . \ldots$

2. Tergite IX consisting of two large, parallel-sided caudolateral projections with narrow basal connection ; antenna with 4 flagellomeres ; setae on wing spinelike (Fig. 2, 3 A-C) ; Holarctic

M. longipennis (Holmgren) Tergite IX large, rounded, occasionally with indication of division ; antenna with 5 flagellomeres ; setae on wing bristle-like (Fig. 3 D-F, 4 E) ; Siberia ... .................M. sibiricus (Lundström)

3. Tergite IX large, sharply triangular ; segment $X$ with sharply pointed corners (Sæther 1977, Fig. 52 A-D) ; Nearctic ................ knabi Coquillett Tergite IX bluntly triangular to rounded or square ; segment $\mathrm{X}$ with rounded, angular or bluntly triangular corners ....................4

4. Front tibia without spur, gonocoxite IX swollen laterally (Cranston \& Judd, Fig. 2 c-e) ; Nearctic ... M. yaquina Cranston et Judd Front tibia with spur, gonocoxite IX with broad apicomedian projection or relatively small without projection $\ldots \ldots \ldots \ldots \ldots \ldots \ldots \ldots \ldots$

5. Gonocoxite IX relatively large, with broad apicomedian projection $\ldots \ldots \ldots \ldots \ldots \ldots \ldots \ldots 6$ Gonocoxite IX relatively small, without apicomedian projection $\ldots \ldots \ldots \ldots \ldots \ldots \ldots \ldots \ldots$

6. Subcosta with $0-2$ setae, cell $m$ basally of RM with 0-9 setae ; apicomedian projection of gonocoxite IX low (Sæther 1989a, Fig. 11 E-G) ; Palaearctic ... .................... ursinus (Holmgren) Subcosta with 43-118 setae, cell $m$ basally of RM with 80-330 setae ; apicomedian projection of gonocoxite IX well developed .................. 7

7. Gonocoxite IX with about 10 setae, spermathecal duct with well developed bulbs; Palaearctic ........ .................. albolineatus (Meigen) Gonocoxite IX with 23-36 setae, spermathecal ducts with weak bulbs (Sæther 1989a, Fig. 8) as M. obscuripes ; Holarctic ......M. eurynotus (Holmgren)

8. Gonocoxite IX with about 24 setae, cercus slightly shorter than notum (Fig. 7 E) ; Palaearctic

.................... atriclava Kieffer Gonocoxite IX with 5-12 setae, cercus shorter than or distinctly longer than notum ...........9

9. Squama with 7 setae (Chaudhuri et al. 1989, Fig. 4e);

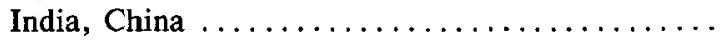
.....M. unilinearis Chaudhuri et Bhattacharyay Squama with more than 20 setae ......... 10

10. Gonocoxite IX with 4-5 setae (Chaudhuri et al. 1989,

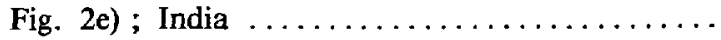
....M. amplispinus Chaudhuri et Bhattacharyay Gonocoxite IX with $9-12$ setae .......... 11 
11. Sternite VIII forming distinct floor, cercus shorter than notum (Fig. 5 C-F) ; Holarctic ........... $\ldots \ldots \ldots \ldots \ldots \ldots \ldots . M$. intergerivus sp. $\mathrm{n}$. Sternite VIII do not form distinct floor, cercus clearly longer than notum (Fig. 7 B-D) ; Holarctic and Oriental ..................... picipes Meigen

Note : $M$. albolineatus, $M$. atriclava, $M$. intergerivus and $M$. picipes all are tentatively associated.

\subsection{The eurynotus group}

Metriocnemus wangi sp. n. (Fig. 1 A)

Type material : Holotype $\sigma$ China : Sichuan, Mt. Jinfo, 10.V.1986, X. Wang (ZMB No. 143). Paratypes $2 \sigma^{\circ}$, as holotype (XW).

Diagnostic characters : The male imago is separable from all other members of the eurynotus group except $M$. albolineatus by the short virgal spines (about $26 \mu \mathrm{m}$ long), subcosta with $42-70$ setae and cell $\mathrm{m}$ with 113-144 setae. It differs fron $M$. albolineatus by having an AR of 0.5-0.6 and a much shorter anal point.

Male imago ( $\mathrm{n}=3$, except when otherwise stated).

Total length $2.57-2.78 \mathrm{~mm}$. Wing length 1.49-1.66 mm. Total length/wing length 1.67-1.72. Wing length/length of profemur 2.16-2.26. Coloration brownish black.

Head. AR 0.54-0.59. Ultimate flagellomere 244-263 $\mu \mathrm{m}$ long. Temporal setae $24-31$, including
17-21 inner verticals, 4-6 outer verticals, and 2-4 postorbitals. Tentorium 135-148 $\mu \mathrm{m}$ long, 34-38 $\mu \mathrm{m}$ wide. Stipes 131-143 $\mu \mathrm{m}$ (2) long, 56-60 $\mu \mathrm{m}$ (2) wide. Palp segments lengths (in um) : 32-34, 4b-45, 173-186, 154-161, 173-184. Third palpal segment with 1 lanceolate apical sensillum clavatum.

Thorax. Antepronotum with 10 setae. Dorsocentrals 34-47, including 12-19 on humeral area ; acrostichals about 21-32, prealars 25-32 ; supraalars 2-3. Scutellum with $30-42$ setae.

Wing. VR 1.25-1.26. C extension 113-158 $\mu \mathrm{m}$ long. Axillary sclerite with $2-4$ setae, brachiolum with 7-8, C extension with 13-24 non-marginal setae, Sc with $42-70, R$ with $62-68, R_{1}$ with $40-63, R_{4+5}$ with 57-115, RM with $5, M$ with $19-28, M_{1}+2$ with 70-82, $\mathrm{M}_{3+4}$ with $45-61, \mathrm{Cu}$ with $36-49, \mathrm{Cu}_{1}$ with 33-39. Pcu with 76-118, and An with 50-58 setae. Wing membrane with setae covering most cells, with 113-144 setae in cell $\mathrm{m}$ basally of RM. Squama with 20-23 (2) up to $146 \mu \mathrm{m}$ long setae.

Legs. Spur of front tibia $45-40 \mu \mathrm{m}$ long, spurs of middle tibia 36-41 $\mu \mathrm{m}$ and 32-36 $\mu \mathrm{m}$ long, of hind tibia 56-64 $\mu_{\mu} \mathrm{m}$ (2) and 32-39 $\mu^{\mathrm{m}}$ (2) long. Width at apex of front tibia $39-41 \mu \mathrm{m}$, of middle tibia $39-45 \mu \mathrm{m}$, of hind tibia $51-53 \mu \mathrm{m}$. Comb of 10 setae, $23-56 \mu \mathrm{m}$ long. Tarsomere 1 of middle and hind legs each with 2 pseudospurs 23-32 $\mu \mathrm{m}$ long, tarsomere 2 of middle leg with 1 pseudospur $23 \mu \mathrm{m}$ (2) long, tarsomere 2 of hind leg without pseudospur. Lengths (in $\mu \mathrm{m}$ ) and proportions of legs :

\begin{tabular}{|c|c|c|c|c|c|c|c|c|c|c|c|}
\hline & $\mathrm{fe}$ & $\mathrm{ti}$ & $\mathrm{ta}_{1}$ & $\operatorname{ta}_{2}$ & $\mathrm{ta}_{3}$ & $\mathrm{ta}_{4}$ & $\mathrm{ta}_{5}$ & LR & BV & SV & BR \\
\hline $\mathrm{p}_{1}$ & $690-757$ & 803- 907 & $524-576$ & 288-331 & $217-246$ & $146-180$ & $80-90$ & $0.63-0.65$ & $2.63-2.75$ & $2.85-2.91$ & $2.7-3.3$ \\
\hline $\mathrm{p}_{2}$ & $728-860$ & $775-860$ & $331-359$ & $194-217$ & $151-180$ & $104-132$ & $66-80$ & $0.40-0.43$ & $3.41-3.56$ & $4.54-4.94$ & $3.1-3.3$ \\
\hline $\mathrm{p}_{3}$ & $794-1002$ & 973-1087 & 454-501 & $255-298$ & $208-241$ & $142-161$ & $76-90$ & $0.46-0.47$ & $3.21-3.28$ & $3.90-4.17$ & $3.8-4.4$ \\
\hline
\end{tabular}

Hypopygium (Fig. 1A). Anal point proper $24-28 \mu \mathrm{m}$ long, tapering to pointed apex ; with $20-24$ setae at base on tergite IX; laterosternite IX with 6-8 setae.

Phallapodeme 79-94 $\mu \mathrm{m}$ long, transverse sternapodeme $75-98 \mu \mathrm{m}$ long. Virga $26 \mu \mathrm{m}$ (1) long, consisting of about 7 spines. Gonocoxite 219-225 $\mu \mathrm{m}$ long, inferior volsella relatively low ending at $0.58-0.60$ gonocoxite length. Gonostylus
113-116 $\mu \mathrm{m}$ long, crista dorsalis bluntly triangular, megaseta $8 \mu \mathrm{m}$ long. HR 1.93-1.97, HV 2.27-2.43.

\section{Remarks}

The species is close to $M$. albolineatus sharing the short virga and general wing chaetotaxy. However, it has a much shorter AR, more hairy wing and quite different anal point. 
Metriocnemus brusti Sæther

Metriocnemus brusti Sæther, 1989a : 407

New material examined : China : Inner Mongolia, Alax, 1 ơ, 31.VIII. 1987, X. Wang (XW No. 1046) ; Qinghai, Menyan, $1 \sigma$, 14.VII.1989, X. Wang (XW No. 1047).

These specimens are slightly smaller those mentioned in Sæther (1989a), with a wing length of $1.85-1.95 \mathrm{~mm}$, an AR of 1.66-1.78; $\mathrm{R}$ with only 28-35 setae, $R_{1}$ with $19-24, R_{4+5}$ with 21-45, Cu with 19-35, $\mathrm{M}_{3+4}$ with 21-44 and An with 26 setae. Other details are in accordance with the previous description.

The species was previously known from Northern Manitoba, Canada.

Metriocnemus acutus sp. n. (Fig. 1 B)

Type material : Holotype $\sigma^{\circ}$, Norway : NordTrøndelag, Høylandet, Skiftesåaa, 18.VI.1988, K. Aagaard (ZMB No. 144).

Diagnostic characters : The male imago is separable from other members of the eurynotus group by the sharply pointed crista dorsalis ; an AR of about 2.2 ; and relatively sparsely haired wing with about 1 seta on Sc, none on M, 24 on Pcu, 6 setae in cell $\mathrm{m}$, and 27 setae on squama.

Male imago $(n=1)$

Total length $3.54 \mathrm{~mm}$. Wing length $2.24 \mathrm{~mm}$. Total length/wing length 1.58 . Wing length/length of profemur 2.52. Coloration brownish black including scutellum, haltere brown.

Head. AR 2.20. Ultimate flagellomere $728 \mu \mathrm{m}$ long. Temporal setae 19 , including 8 inner verticals, 8 outer verticals, and 3 postorbitals. Clypeus with 39 setae. Tentorium $58 \mu \mathrm{m}$ long, $39 \mu \mathrm{m}$ wide. Stipes $150 \mu \mathrm{m}$ long, $101 \mu \mathrm{m}$ wide. Palp segments lengths (in $\mu \mathrm{m}$ ) : 38, 62, 236, 165, 156. Third palpal segment with 1 long, lanceolate apical sensillum clavatum.

Thorax : Antepronotum with 7 setae. Dorsocentrals 67 , including about 20 on humeral area ; acrostichals 38 ; prealars 43 ; supraalars 3 . Scutellum with 39 setae.

Wing. VR 1.21. C extension $131 \mu \mathrm{m}$ long. $C$ extension with 10 non-marginal setae, Sc with 1 , $R$ with $39, R_{1}$ with $22, R_{4+5}$ with $51, R M$ with none, $M$ with none, $M_{1+2}$ with $64, M_{3+4}$ with 43 , $\mathrm{Cu}$ with $20, \mathrm{Cu}_{1}$ with $28, \mathrm{Pcu}$ with 24 , and An with 26 setae. Wing membrane with setae covering most cells, but sparsely haired basally with 6 setae in cell m basally of RM. Squama with 27 setae.

Legs. Spur of front tibia $79 \mu \mathrm{m}$ long, spurs of middle tibia $41 \mu \mathrm{m}$ and $30 \mu \mathrm{m}$ long, of hind tibia about $80 \mu \mathrm{m}$ and $30 \mu \mathrm{m}$ long. Width at apex of front tibia $45 \mu \mathrm{m}$, of middle tibia $49 \mu \mathrm{m}$, of hind tibia $64 \mu \mathrm{m}$. Comb with 13 setae, 38-68 $\mu \mathrm{m}$ long. Tarsomeres 1 and 2 of middle leg each with 2 pseudospurs, $30 \mu \mathrm{m}$ long. Hind tarsomeres lost. Lengths (in $\mu \mathrm{m}$ ) and proportions of legs :

\begin{tabular}{ccccccccccc}
\hline & $\mathrm{fe}$ & $\mathrm{ti}$ & $\mathrm{ta}_{1}$ & $\mathrm{ta}_{2}$ & $\mathrm{ta}_{3}$ & $\mathrm{ta}_{4}$ & $\mathrm{ta}_{5}$ & $\mathrm{LR}$ & $\mathrm{BV}$ & $\mathrm{SV}$ \\
\hline $\mathrm{p}_{1}$ & 888 & 1068 & 376 & 383 & - & - & - & 0.54 & - & 3.39 \\
$\mathrm{p}_{2}$ & 926 & 1030 & 416 & 236 & 170 & 118 & 95 & 0.40 & 3.83 & 4.70 \\
$\mathrm{p}_{3}$ & 1021 & 1276 & - & - & - & - & - & - & - & - \\
\hline
\end{tabular}

Hypopygium (Fig. 1 B). Anal point proper $45 \mu \mathrm{mm}$ long, tapering to narrow blunt apex ; with 44 setae at base on tergite IX ; laterosternite IX with 9 setae.

Phallapodeme $105 \mu \mathrm{m}$ long ; transverse sternapodeme $135 \mu \mathrm{m}$ long, with well developed oral projections. Virga $53 \mu \mathrm{m}$ long, consisting of about 10 spines.

Gonocoxite $240 \mu \mathrm{m}$ long, inferior volsella relatively low, ending at 0.73 of gonocoxite length. Gonostylus
$109 \mu \mathrm{m}$ long, crista dorsalis sharply triangular, megaseta $11 \mu \mathrm{m}$ long. HR 2.21, HV 3.25.

\section{Remarks}

This species together with $M$. dentipalpus sp. $\mathrm{n}$. and $M$. brusti apparently form a monophyletic group. It differs from the other two species in having a sharply pointed crista dorsalis, higher antennal ratio, longer costal extension, generally fewer setae on the wing, but more numerous acrostichals and dorsocentrals (especially on the humeral area). 


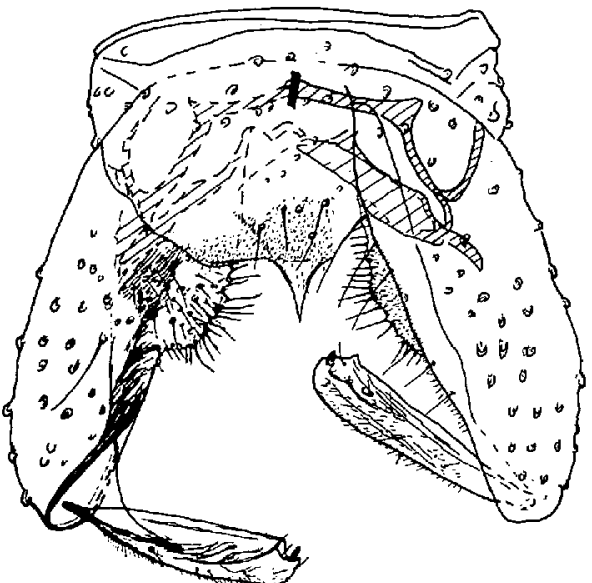

A

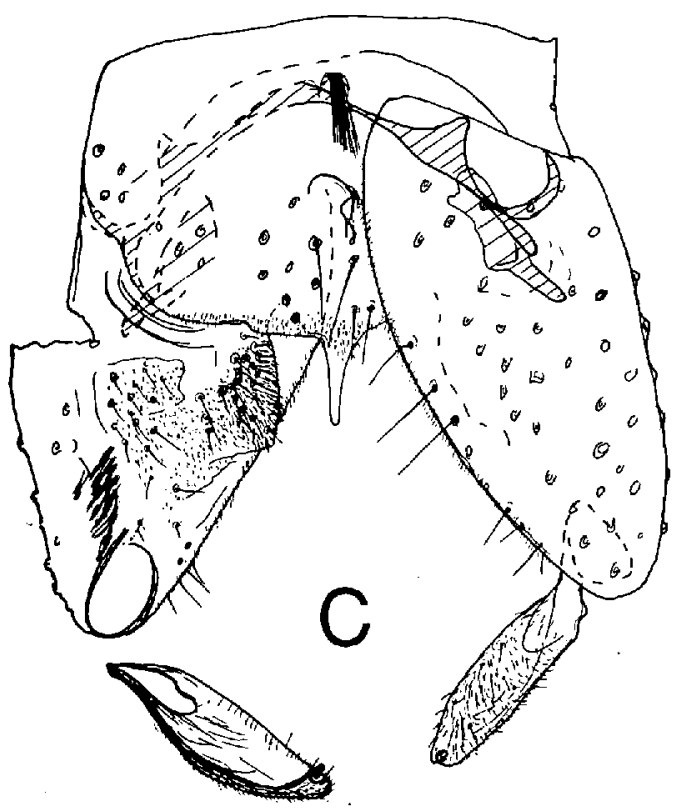

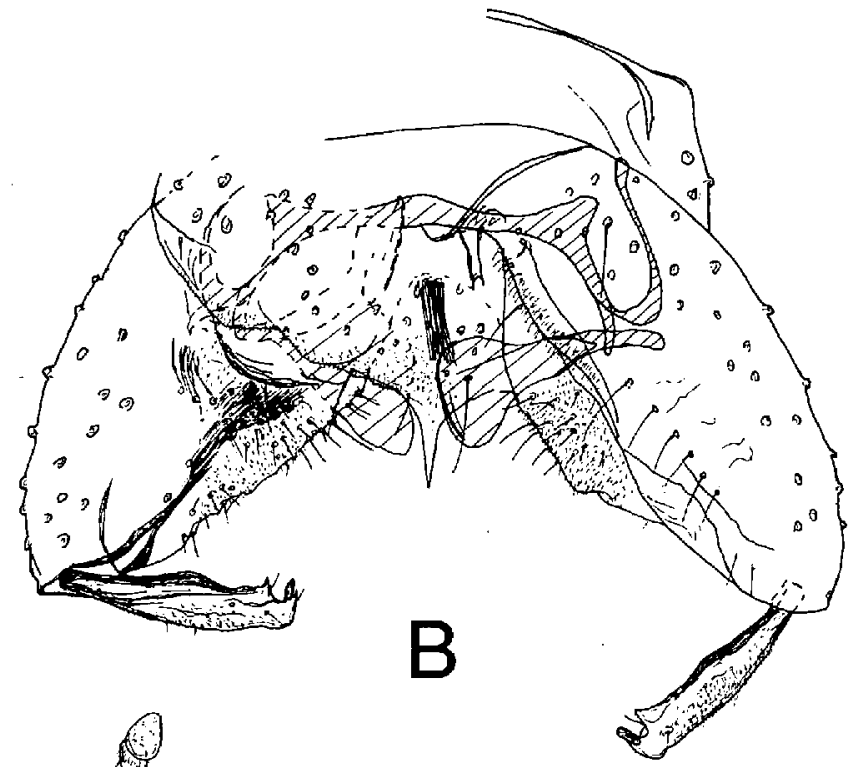
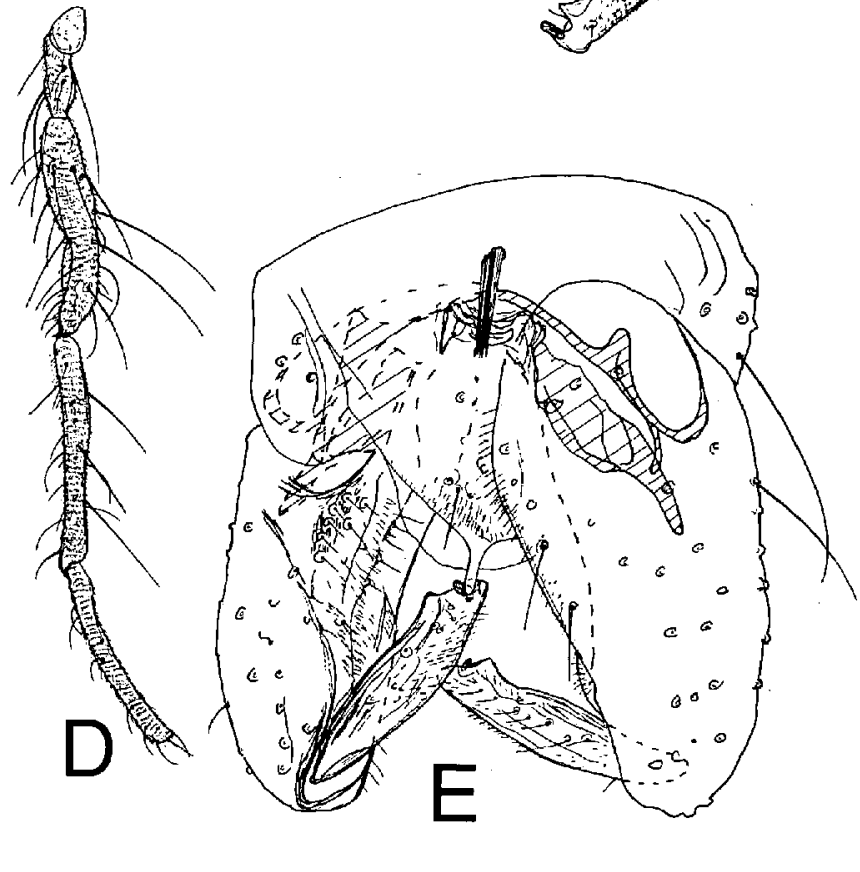

Fig. 1. Metriocnemus spp., male imagines : A. M. wangi sp. n., hypopygium ; B. M. acutus sp. n., hypopygium ; C-D. M. dentipalpus sp. ח., palp (C) and hypopygium (D) ; E. M. calvescens sp. n., hypopygium.

Fig. 1. Metriocnemus spp., imagos mâles : A. $M$. wangi n. sp., hypopyge ; B. M. acutus n. sp., hypopyge ; C-D. M. dentipalpus, n. sp., palpe (C) et hypopyge (D) ; E. M. calvescens n. sp., hypopyge. 
Metriocnemus dentipalpus sp. n (Fig. 1 C, D)

Type material : Holotype $\sigma$, China : Xizang (Tibet), Dingri, 16.IX.1987, C. Deng. (ZMB No. 145).

Diagnostic characters : The male imago can be seperated from the similar $M$. brusti and $M$. acutus by having 20 setae on vein $M$, an AR of 1.43, palp with a small apical tooth on each of palpomeres 3 and 4, and anal point with concave margins.

Male imago $(\mathbf{n}=1)$

Wing length $2.12 \mathrm{~mm}$. Wing length/length of profemur 2.57. Coloration dark brown including scutellum, halteres brown.

Head. AR 1.43. Ultimate flagellomere $510 \mu \mathrm{m}$ long. Temporal setae 20 , including 8 inner verticals, 6 outer verticals, and 6 orbitals. Clypeus with 29 setae. Tentorium $161 \mu \mathrm{m}$ long, $47 \mu \mathrm{m}$ wide. Stipes $161 \mu \mathrm{m}$ long, $60 \mu \mathrm{m}$ wide. Palp segments lengths (in $\mu \mathrm{m}$ ) : 38, 64, 165, 169, 150. Third palpomere (Fig. $1 \mathrm{C})$ with 2 preapical lanceolate sensilla clavata and small sclerotized apical tooth, fourth flagellomere with similar apical tooth.

Thorax. Antepronotum with 9 setae. Dorsocentrals about 30 , including 8 on humeral area ; acrostichals about 15 ; prealars 29 ; supraalars 2 . Scutellum with about 34 setae.

Wing. VR 1.11. C extension $94 \mu \mathrm{m}$ long. Brachiolum with 6 setae, extension with 11 , Sc with $3, R$ with $29, R_{1}$ with $34, R_{4+5}$ with $32, R M$ with $4, M$ with $20, M_{1+2}$ with $48, M_{3+4}$ with 33, Cu with 38 , $\mathrm{Cu}_{1}$ with $25, \mathrm{Pcu}$ with 8 , and An with 40 setae. Wing membrane with setae covering most cells, but sparsely haired basally with 27 setae in cell $\mathrm{m}$ basad of RM. Squama with 27 setae, 41-109 $\mu \mathrm{m}$ long.

Legs. Spur of front tibia $68 \mu \mathrm{m}$ long, spurs of middle tibia $47 \mu \mathrm{m}$ and $38 \mu \mathrm{m}$ long, of hind tibia $98 \mu \mathrm{m}$ and $38 \mu \mathrm{m}$ long. Width at apex of front tibia $49 \mu \mathrm{m}$, of middle tibia $49 \mu \mathrm{m}$, of hind tibia $60 \mu \mathrm{m}$ long. Comb of 10 setae, $26-60 \mu \mathrm{m}$ long. Tarsomere 1 of middle and hind legs each with 2 pseudospurs 26-34 $\mu \mathrm{m}$ long, tarsomeres 2 without pseudospurs. Lengths (in $\mu \mathrm{m}$ ) and proportions of legs :

\begin{tabular}{cccccccccccc}
\hline & $\mathrm{fe}$ & $\mathrm{ti}$ & $\mathrm{ta}_{1}$ & $\mathrm{ta}_{2}$ & $\mathrm{ta}_{3}$ & $\mathrm{ta}_{4}$ & $\mathrm{ta}_{5}$ & $\mathrm{LR}$ & $\mathrm{BV}$ & $\mathrm{SV}$ & $\mathrm{BR}$ \\
\hline $\mathrm{p}_{1}$ & $\mathbf{8 2 2}$ & 907 & 510 & 321 & 236 & 151 & 113 & 0.56 & 2.72 & 3.39 & 3.1 \\
$\mathrm{p}_{2}$ & $\mathbf{8 5 1}$ & 879 & 350 & 208 & 161 & 123 & 95 & 0.40 & 3.49 & 4.95 & 2.7 \\
$\mathrm{p}_{3}$ & $\mathbf{9 3 1}$ & 1106 & 539 & 312 & 236 & 151 & 113 & 0.49 & 3.17 & 3.78 & 5.0 \\
\hline
\end{tabular}

Hypopygium (Fig. 1 D). Anal point proper $43 \mu \mathrm{m}$ long, tapering to blunt apex ; with 29 setae at base on tergite IX ; laterosternite IX with 7 setae. Phallapodeme $88 \mu \mathrm{m}$ long, transverse sternapodeme $126 \mu \mathrm{m}$ long. Virga $49 \mu \mathrm{m}$ long, consisting of about 10 spines. Gonocoxite $248 \mu \mathrm{m}$ long ; inferior volsella low, ending at 0.72 gonocoxite length, but with a distinct angle at 0.60 . Gonostylus $116 \mu \mathrm{m}$ long ; crista dorsalis small, bluntly triangular, megaseta $11 \mu \mathrm{m}$ long. HR 2.13.

\section{Remarks}

This species is very close to $M$. brusti differing primarily in the more numerous setae on $M$, the teeth on the palp and possibly in details of the hypopygium.

\section{Metriocnemus eurynotus (Holmgren)}

Chironomus eurynotus Holmgren, 1883 : 179

Chironomus obscuripes Holmgren, 1869 : 38, preoccupied by Chironomus obscuripes Meigen, $1830: 244$ (= Glyptotendipes glaucus Meigen, 1818) Nomenclatorial note : The junior homonomy was overlooked by Sæther $(1989 \mathrm{a}: 410)$ as well as by Ashe \& Cranston $(1990: 199,282)$, but is mentioned by Sublette \& Sublette (1965: 161). A more complete list of synonyms is given in Sæther (1989a).

New material examined : China : Ghasu, Hezo, 1 ơ, 16.VII.1986, X. Wang, Sichuan, Mt. Jinfo, $1 \sigma^{\circ}, 9$. V.1986, X. Wang (XW). Burma : Kambaiti, 2000 m.a.s.l., 5 ơ, 1 \%, 1934, Malaise (No. 230b) (ZMB). Norway : Hedmark, Storelvdal, Storbekken, Malaise trap at stream, $2 \sigma, 29$. VIII.1988, 
K. Aagaard (KA) ; Oppland, Dovre, Atna river, Skranglehaugan, Malaise traps, $6 \sigma^{\circ}$, 18.VI.-8.VIII.1986, K. Aagaard (KA) ; Oppland, Dovre, Atna river, Dørålseter, Malaise traps, $4 \sigma$, 25.VI-16.VIII.1986, K. Aagaard (KA); Nord Trøndelag, Høylandet, Skiftesåa, trap no.2, 3 \% , 18.VI.-30.VII.1986, K. Aagaard (KA).

\section{Remarks}

Sasa et al. (1988 : 53) mentions $M$. eurynotus (as hygropeticus) from Japan. According to their figures of the wing and the hypopygium their species, however, most likely is $M$. brusti. The present record from China thus is the most easterly Palaearctic record.

\section{Metriocnemus ursinus (Holmgren)}

Chironomus ursinus Holmgren, 1869 : 30.

New material examided: Norway: Svalbard, Spitzbergen, on Deschampsia, $1 \%$, 9.VII.1975, KFNI (KA).

\section{Metriocnemus calvescens sp. n. (Fig. 1 E)}

Type material. Holotype ơ, China : Quinghai, Menyuan, 13.VII.1989, W. Wei (ZMB No. 145).

Diagnostic characters : The male imago can be separated from similar $M$. ursinus by its smaller size (wing length about $2.5 \mathrm{~mm}$ ), only 27 setae in cell $r_{4+5}$, only 27 setae on squama, only 26 setae on scutellum, and presence of pseudospurs on front metatarsus.
Male imago $(n=1)$

Total length $4.00 \mathrm{~mm}$. Wing length $2.51 \mathrm{~mm}$. Total length/wing length 1.59 . Wing length/length of profemur 2.86. Coloration brownish black including scutellum, haltere brown.

Head. AR 2.60. Ultimate flagellomere $829 \mu \mathrm{m}$ long. Temporal setae 26 , including 12 inner verticals, 8 outer verticals, and 6 postorbitals. Clypeus with 30 setae. Tentorium $191 \mu \mathrm{m}$ long, $56 \mu \mathrm{m}$ wide. Stipes $165 \mu \mathrm{m}$ long, $94 \mu \mathrm{m}$ wide. Palp segments lengths (in $\mu \mathrm{m}$ ) : 49, 75, 248, 184, 191. Third palpal segment with 1 lanceolate sensillum clavatum.

Thorax. Antepronotum with 9 setae. Dorsocentrals 48 , including 11 on humeral area ; acrostichals apparently few in number ; prealars 41 ; supraalars 4. Scutellum with 26 setae.

Wing. VR 1.20. C extension $116 \mu \mathrm{m}$ long. Brachiolum with 6 setae, $C$ extension with $4, R$ with 17 , $\mathrm{R}_{1}$ with $5, \mathrm{R}_{4+5}$ with $6, \mathrm{M}_{1+2}$ with $5, \mathrm{M}_{3+4}$ with $13, \mathrm{Cu}$ with $1, \mathrm{Cu}_{1}$ with 4 , An with 9 setae, other veins bare. Wing membrane with 27 setae in cell $r_{4+5}$, other cells bare. Squama with 27 setae, 79-210 $\mu \mathrm{m}$ long.

Legs. Spur of front tibia $94 \mu \mathrm{m}$ long, spurs of middle tibia $41 \mu \mathrm{m}$ long and $34 \mu \mathrm{m}$ long, of hind tibia $90 \mu \mathrm{m}$ and broken. Width at apex of front tibia $56 \mu \mathrm{m}$, of middle tibia $53 \mu \mathrm{m}$, of hind tibia $64 \mu \mathrm{m}$. Tarsomeres 1 and 2 on middle and hind legs each with 2 pseudospurs 30-38 $\mu \mathrm{m}$ long. Lengths (in $\mu \mathrm{m}$ ) and proportions of legs :

\begin{tabular}{rrrrrrrrrrrr}
\hline & $\mathrm{fe}$ & $\mathrm{ti}$ & $\mathrm{ta}_{1}$ & $\mathrm{ta}_{2}$ & $\mathrm{ta}_{3}$ & $\mathrm{ta}_{4}$ & $\mathrm{ta}_{5}$ & $\mathrm{LR}$ & $\mathrm{BV}$ & $\mathrm{SV}$ & $\mathrm{BR}$ \\
\hline $\mathrm{p}_{1}$ & 879 & 1058 & 633 & 387 & 246 & 151 & 113 & 0.60 & 2.86 & 3.06 & 3.1 \\
$\mathrm{p}_{2}$ & 964 & 1068 & 397 & 250 & 180 & 128 & 109 & 0.37 & 3.65 & 5.12 & 2.5 \\
$\mathrm{p}_{3}$ & 1040 & 1304 & 643 & 369 & 284 & 161 & 123 & 0.49 & 3.19 & 3.65 & 5.0 \\
\hline
\end{tabular}

Hypopygium (Fig. 1 E). Anal point proper $41 \mu \mathrm{m}$ long, nearly parallel-sided with rounded apex ; with 39 setae at base on tergite IX ; laterosternite IX with 10 setae. Phallapodeme $113 \mu \mathrm{m}$ long, transverse sternapodeme $116 \mu \mathrm{m}$ long. Virga $45 \mu \mathrm{m}$ long, consisting of about 10 spines. Gonocoxite $263 \mu \mathrm{m}$ long ; inferior volsella very low, ending at 0.79 gonocoxite length. Gonostylus $124 \mu \mathrm{m}$ long, crista dorsalis bluntly triangular, megaseta $11 \mu \mathrm{m}$ long. HR 2.12, HV 3.23.

\section{Remarks}

This species apparently forms the sister species of M. ursinus.

\section{Metriocnemus longipennis (Holmgren)}

(Figs 2, 3 A-C)

Smittia longipennis (Holmgren), 1883 : 18.

Dolichoprymna longipennis (Holmgren) ; Lundström $1915: 22$. 
Metriocnemus longipennis (Holmgren) ; Edwards 1929 : 357 ; Sæther $1986: 215,1989 a$ : 421.

New material examined : Russia : Siberia, New Siberian Islands, Holzgebirge, $1 \sigma, 2 \%$, 16-19.VI.1903, M.I. Brussnew ; Chara Ullach Mts, at Chara-Ullach river, 1 \& , 27.VI.1902, M.I. Brussnew (ZIS).

The male imago was described by Sæther 1989a : 421. The male examined here is slightly larger (gonostylus length $221 \mu \mathrm{m}$ ) and has generally higher chaetotaxy with 13 setae on squama, 52 dorsocentrals, 38 acrostichals, 7 preepisternals and 37 setae on scutellum. In other details it is nearly identical with the Nearctic specimens.

Diagnostic characters for the female imago : The two, large, parallel-sided, caudolateral projections with relatively narrow basal connection constituting tergite IX will separate the species from all other known species of the genus. The spine-like setae on the wing as well as the antenna with only 4 flagellomeres also are unique within the genus.

Female imago ( $n=3$, except when otherwise stated)

Total length $5.23-5.43 \mathrm{~mm}$. Wing length 1.73-2.12 mm. Total length/wing length 2.47-3.09. Wing length/length of profemur 1.69-2.04. Coloration brown including wing and haltere.

Head (Fig. 2 A). AR 0.65-1.10. Lengths (in $\mu \mathrm{m}$ ) of flagellomeres (Fig. 2 B) : 101-150, 56-71, 43-75, 143-255. Longest sensilla chaetica on flagellomeres .23-26 $\mu \mathrm{m}$ long. Pedicel with 1-7 setae. Temporal setae 48-57, including 23-32 inner verticals, 12-13 outer verticals, and 10-14 postorbitals. Clypeus with
35-38 setae. Tentorium 169-244 $\mu \mathrm{m}$ long, 26-38 $\mu \mathrm{m}$ wide. Stipes $169 \mu \mathrm{m}$ (1) long, $101 \mu \mathrm{m}$ (1) wide. Palp segments length/width (in $\mu \mathrm{m}$ ) : 45-49/41-45, 56-73/64, 113-135/60-71, 83-98/60-73, 86-105/41-58. Coronal suture absent.

Thorax (Fig. 2 C). Antepronotum with 16-23 lateral setae. Dorsocentrals 67-72, acrostichals 38-39 (2), prealars 30-39, supraalars 5-6, preepisternals 0-1. Scutellum with $46-50$ setae.

Wing (Fig. 2 D-E). VR 1.04-1.08. Shape quite variable, anal lobe absent to relatively well developed. C extension 38-79 $\mu \mathrm{m}$ (2) long. Brachiolum with 10-11 setae, $C$ extension with 4-6 (2) nonmarginal setae, $S c$ with $1-6, R$ with $58-67, R_{1}$ with 38-50, $R_{4+5}$ with 60-95, RM with 0-3, $M$ with 11-20, $\mathrm{M}_{1+2}$ with $33-49 ; \mathrm{M}_{3+4}$ with 51-66, Cu with 36-50, $\mathrm{Cu}_{1}$ with 38-40, Pcu with 0-2, An with 48-70 setae. Wing membrane with $1-5$ setae in cell $\mathrm{c}$, cell $\mathrm{m}$ basally of $\mathrm{RM}$ with 36 setae, cell $\mathrm{m}_{1+2}$ with 44-94, celle $\mathrm{m}_{3+4}$ with $4-35$, cell $\mathrm{cu}_{1}$ with $6-56$, and cell an with 46-190 setae. Axillary sclerite with 2-3 (2) setae. Squama with 4-10 setae.

Legs. Spur of front tibia 60-64 $\mu \mathrm{m}$ long, spurs of middle tibia $49-60 \mu \mathrm{m}$ and $53 \mu \mathrm{m}$ long, of hind tibia $113 \mu \mathrm{m}$ and 23-49 $\mu \mathrm{m}$ long. Width at apex of front tibia 83-90 $\mu \mathrm{m}$, of middle tibia $94 \mu \mathrm{m}$, of hind tibia 90-113 $\mu \mathrm{m}$. Comb with 13-17 setae, longest seta 71-75 $\mu \mathrm{m}$ long, shortest seta 41-49 $\mu \mathrm{m}$ long. Tarsomeres of middle leg with 3 pseudospurs, $\operatorname{ta}_{2}$ of middle leg with 1-2, $\mathrm{ta}_{1}$ of hind leg with 3-6 (2), $\mathrm{ta}_{2}$ of hind leg with $24, \operatorname{ta}_{3}$ with 1-2 pseudospurs ; pseudospurs $34-53 \mu \mathrm{m}$ long. Lengths (in $\mu \mathrm{m}$ ) and proportions of legs $(n=2-3)$ :

\begin{tabular}{|c|c|c|c|c|c|c|c|c|c|c|c|}
\hline & fe & ti & $\mathrm{ta}_{1}$ & $\mathrm{ta}_{2}$ & $\mathrm{ta}_{3}$ & $\mathrm{ta}_{4}$ & $\mathrm{ta}_{5}$ & LR & BV & SV & BR \\
\hline$p_{1}$ & $945-1040$ & $1068-1106$ & $520-567$ & $288-293$ & 217 & $170(1)$ & $161(1)$ & $0.49-0.52$ & $3.22(1)$ & $3.78 \div 4.05$ & $1.0-1.1$ \\
\hline $\mathrm{p}_{2}$ & $1081-1229$ & $1096-1229$ & $406-501$ & 246-274 & $180-198$ & $104-161$ & $142-161$ & $0.37-0.41$ & $3.70-3.86$ & $4.78-5.57$ & $1.2(1)$ \\
\hline$p_{3}$ & $1295-1323$ & $1427-1607$ & $690-784$ & $359-454$ & $331-378$ & 189 & $151-170$ & $0.48-0.50$ & $3.12-3.31$ & 3.33-3.95 & $1.0-1.4$ \\
\hline
\end{tabular}

Genitalia (Figs 2 F, 3 A-C). Sternite VIII with 52-65 setae. Gonocoxite large, digitiform projection, with rounded apex, with 28-36 setae. Tergite IX (Fig. 3 E) deeply divided into two large, parallel-sided, digitiform projections, with basal connection, shorter than projections, altogether with 46-50 setae. Cercus 169-206 $\mu \mathrm{m}$ long. Seminal capsule
199-255 $\mu \mathrm{m}$ long, including neck, stronger sclerotized in apical 128-143 $\mu \mathrm{m}, 150-165 \mu \mathrm{m}$ wide. Notum 225-248 $\mu \mathrm{m}$ (2) long.

\section{Remarks}

The peculiar shape of tergite IX of the female taken together with the other aberrant features of 

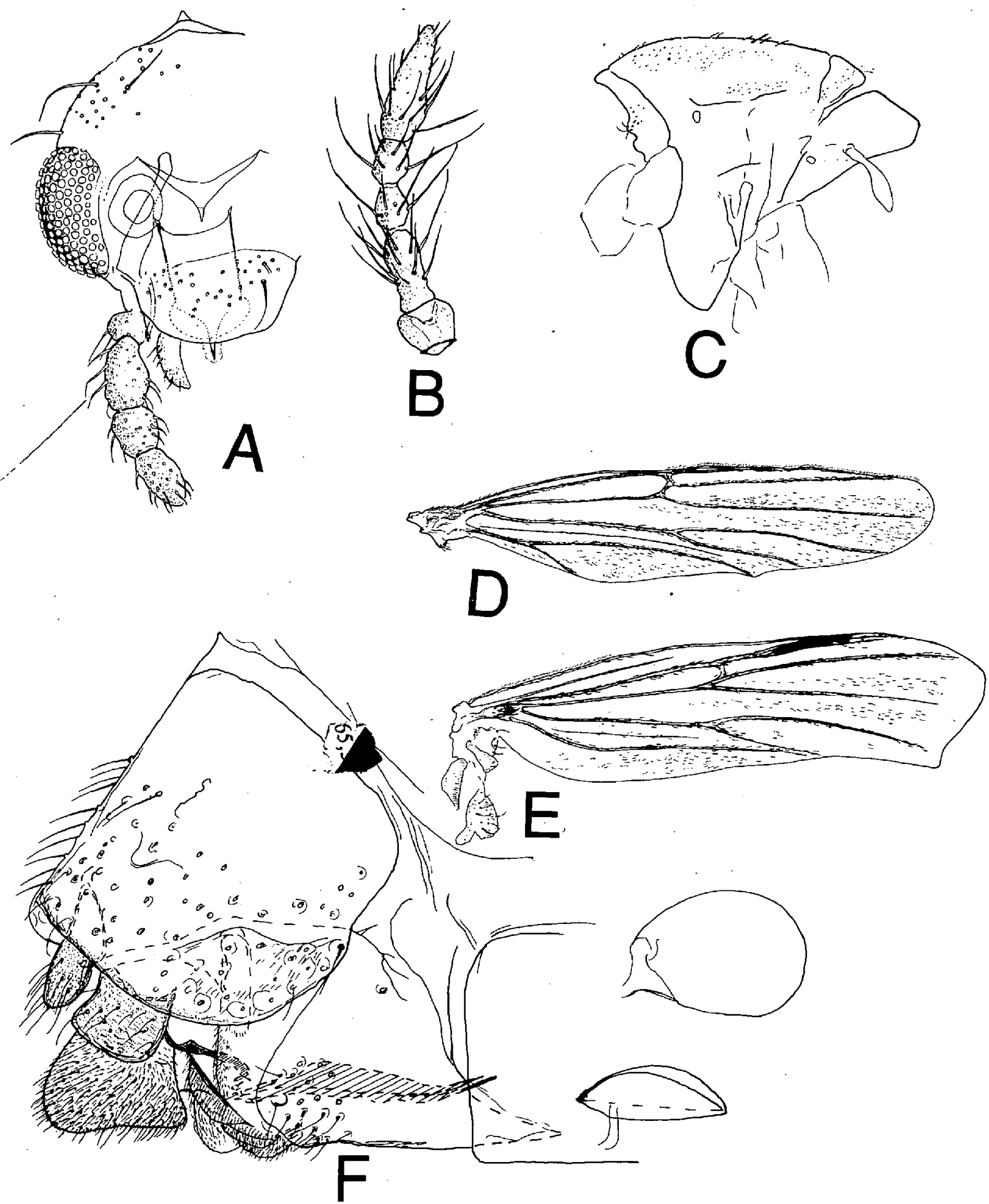

Fig. 2. Metriocnemus longipennis (Holmgren), female imago : A. Head ; B. Antenna ; C. Thorax ; D-E. Variation in wings ; F. Genitalia, lateral view.

Fig. 2. Metriocnemus longipennis (Holmgren), imago femelle : A. Tête : B. Antenne : C. Thorax ; D-E. Variation des ailes ; F. Genitalia, vue latérale. 
this species appears to warrant a separate genus for the species. However, $M$. sibiricus described below has female genitalia quite normal for Metriocnemus, and the male is clearly close to $M$. longipennis.

\section{Metriocnemus sibiricus (Lundström)}

(Figs 3 D-G, 4)

Arctomyia sibirica Lundström, $1915: 19$.

Metriocnemus sibiricus (Lundström), Edwards 1929 : 357, Sæther 1989a : 398.

Metriocnemus (Arctomyia) sibiricus (Lundström) ; Goetghebuer 1940-50: 8, 25.

Type material : Lectototype $\sigma$, here designated, Russia : New Siberian Island, south coast, " Holzgebirge », 16. VI.1903, M. I. Brussnew (ZIS). Paralectotypes $6 \sigma, 3 \%$, as lectotype except 16-23.V.1903 ; New Siberian Islands, Kotelnyj Island, 1 \% , 5.VIII.1901, K. A. Wollosowitsch (ZIS).

Diagnostic characters. The flattened scutum, compressed and triangular preepisternum, short and thick palps etc. will separate the imagines from other Metriocnemus except $M$. longipennis. The male imago has shortened wings and reduced antennal plume as in $M$. longipennis, but 12-13 flagellomeres, normal setae on wing membrane and gonostylus with large median projection. The female imago can be separated from $M$. longipennis by having a large, rounded tergite IX with only indication of a division and 5 flagellomeres.

Male imago $(n=6-8)$

Total length $3.49-4.25,3.84 \mathrm{~mm}$. Wing length $1.35-1.78,1.60 \mathrm{~mm}$. Total length/wing length 2.16-2.58,2.38. Wingh length/length of profemur $1.38-1.63,1.53$. Coloration brown, haltere and wing included.

Head (Fig. 4 C). AR 0.47-0.51,0.49. 11-12, 12 flagellomeres ; flagellomere $1-5$ and ultimate with sensilla chaetica; ultimate flagellomere 229-266, $244 \mu \mathrm{m}$ long. Temporal setae $22-48,32$; including $16-40,24$ inner verticals ; 3-6,4 outer verticals ; and $3-4,4$ outer verticals. Clypeus with $10-29,20$ setae.
Tentorium (Fig. 4 B) 150-206,177 $\mu \mathrm{m}$ long ; $26-38,33 \mu \mathrm{m}$ wide ; with microtrichia in anterior half. Stipes 131-173,160 $\mu \mathrm{m}$ long ; 60-105,80 $\mu \mathrm{m}$ wide. Palp segments length/width in $\mu \mathrm{m}$ : $34-49,41 / 38-53,45 ; 45-71,60 / 45-60,46 ; 120-146$, $131 / 41-56,51 ; 83-109,99 / 49-53,51 ; 94-120,102 /$ $38-47,42$. Coronal suture complete in 3 specimens ; 56-150, $107 \mu \mathrm{m}$ long in 5 specimens.

Thorax (Fig. 4 A). Antepronotum with 2-12,8 setae. Scutum flattened ; preepisternum compressed and triangular ; dorsocentrals $26-46,35$; acrostichals $8-21,15$; prealars $15-25,21$; supraalars $1-3,2$; preepisternum occasionally with indication of single seta ( 2 of 8 specimens). Scutellum with $25-40,32$ setae.

Wing (Fig. 4 D). VR 1.06-1.15,1.12. C extension $64-98,84 \mu \mathrm{m}$ long. Wing narrow with weak anal lobe. Brachiolum with 3-6,5 setae ; Cextension with 3-12,6 non-marginal setae ; $\mathrm{Sc}$ with 4-20,11 setae ; $R$ with 22-38,30; $R_{1}$ with $20-32,25 ; R_{4+5}$ with $18-42,31$; $M$ with $0-2,0$; RM without ; $M_{1+2}$ with $0-22,9 ; \mathrm{M}_{3+4}$ with $48-70,61 ; \mathrm{Cu}$ with $31-42,36$; $\mathrm{Cu}_{1}$ with 30-38,33; Pcu with 0-4,1 ; and An with $38-50,42$ setae. Wing membrane with $3-15,7$ setae in cell basally of RM ; cells $c, r$, and sc occasionally each with 1 seta ; cell $\mathrm{r}_{4+5}$ with about $63-215,150$ setae ; $m_{1+2}$ with about $32-200,110$ setae $; m_{3+4}$ with 11.39 setae; and cell an with about 85-220,17ureiae. Axillary sclerite with 1-2,1 seta. Squama with 3-10,7 setae ; shortest seta 38-56,50 $\mu \mathrm{m}$ long ; longest seta 94-135,111 $\mu \mathrm{m}$ long.

Legs. Spur of front tibia 41-64,54 $\mu \mathrm{m}$ long ; spurs of middle tibia $41-53,44 \mu \mathrm{m}$ and $34-49,40 \mu \mathrm{m}$ long ; of hind tibia $64-83,79 \mu \mathrm{m}$ and $30-45,38 \mu \mathrm{m}$ long. Width at apex of front tibia $56-75,68 \mu \mathrm{m}$; of middle tibia $58-98,73 \mu \mathrm{m}$; of hind tibia $75-94,87 \mu \mathrm{m}$. Comb of $12-14,15$ setae ; shortest seta 26-38,52 $\mu \mathrm{m}$; longest seta 56-68,61 $\mu \mathrm{m}$ long. Tarsomeres 1 and 2 of middle and hind leg each with 2 pseudospurs $19-38,28 \mu \mathrm{m}$ long ; or tarsomere 1 of middle leg occasionally with 3 pseudospurs. Lengths (in $\mu \mathrm{m}$ ) and proportions of legs :

\begin{tabular}{|c|c|c|c|c|c|c|c|c|c|c|c|}
\hline & $\mathbf{f e}$ & ti & $\mathrm{ta}_{1}$ & $\mathrm{ta}_{2}$ & $\mathrm{ta}_{3}$ & $\mathrm{ta}_{4}$ & $\mathrm{ta}_{5}$ & LR & BV & SV & $\mathbf{B R}$ \\
\hline$p_{1}$ & $832-1134,1050$ & $907-1200,1070$ & $506-652-587$ & $302-406,345$ & $232-302-225$ & $170-224,162$ & $123-161,140$ & $0,54-0.57,0.55$ & $2.67-5.07,2,89$ & $3.44-3.71,3.59$ & $1.5-1.9,1.7$ \\
\hline $\mathbf{p}_{2}$ & $851-1125,1025$ & $907-1162,1067$ & $350-444,409$ & $217-284,256$ & $180-208,197$ & $142-170,152$ & $104-151,128$ & $0.37-0.40,0.39$ & $3.23-3.58,3.31$ & $4.90-5.42,5.09$ & $1.3-2.0,1.7$ \\
\hline $\mathbf{p}_{3}$ & $936-1210,1101$ & $1057-1433,1290$ & $567-747,666$ & $331-406,364$ & $255-340,296$ & $161-227,188$ & $123-161,142$ & $0.49-0.53,0.52$ & $2.90-3.34,3.10$ & $3.51-3.70,3.59$ & $1.6-2.0,1.9$ \\
\hline
\end{tabular}



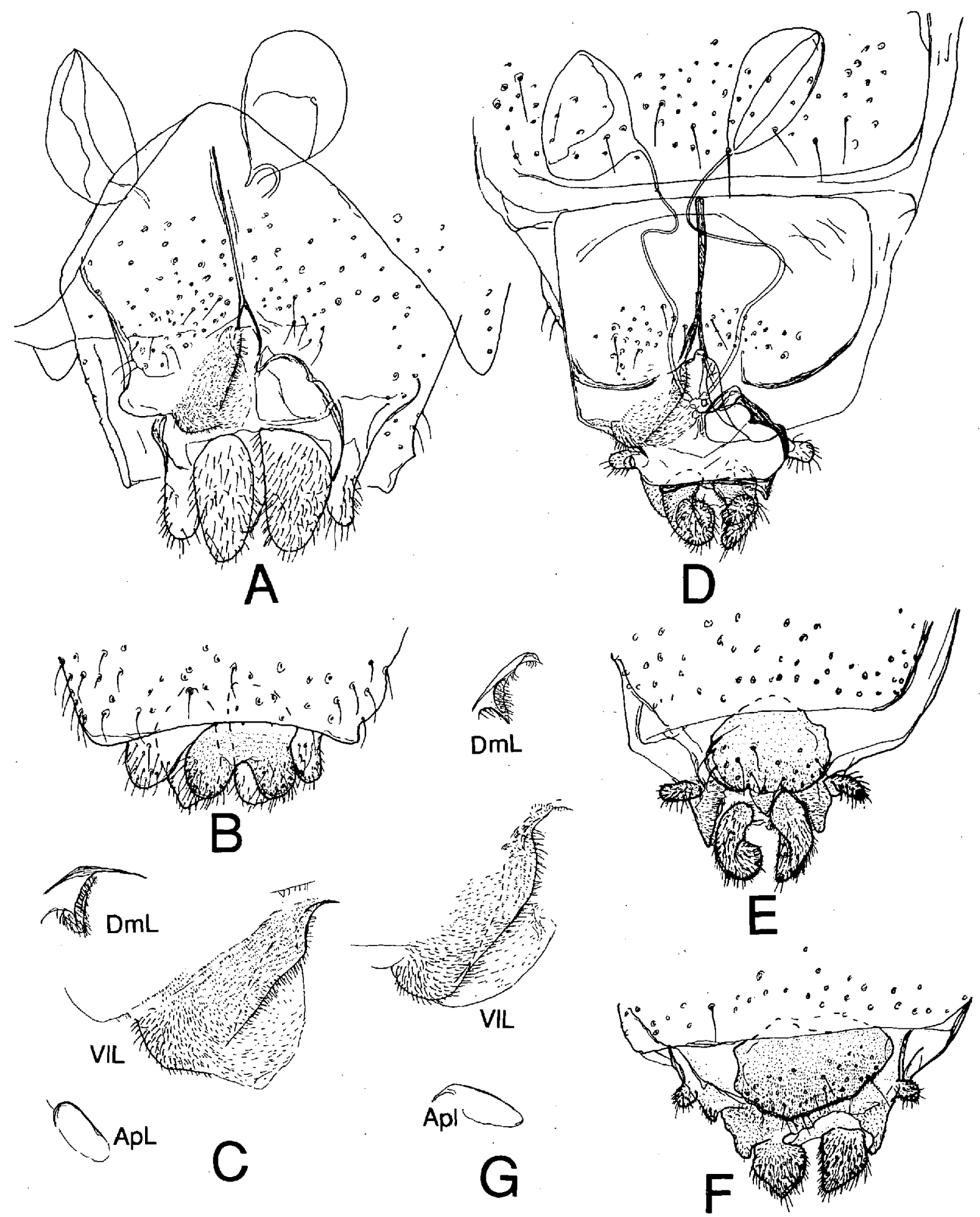

Fig. 3. Metriocnemus spp., female genitalia : A-C. M. longipennis (Holmgren), ventral view (A), dorsal view (D), and lobes of gonapophyses (C) ; D-G. M. sibiricus (Lundström), ventral view (D), dorsal views (E-F), and lobes of gonapophyses (G). (DmL, dorsomesal lobe ; VIL, ventrolateral lobe ; ApL, apodeme lobe).

Fig. 3. Metriocnemus spp., genitalia femelle : A-C. M. longipennis (Holmgren), vue ventrale (A), vue dorsale (D), et lobes des gonapophyses (C) ; D-G. M. sibiricus (Lundström), vue ventrale (D), vues dorsales (E-F), et lobes des gonapophyses (G). (DmL, lobe dorsomésal ; VIL, lobe ventrolatéral ; ApL, lobe apodème. 
Hypopygium (Fig. 4 F). Anal point proper $45-64,51 \mu \mathrm{m}$ long ; tapering to blunt apex ; tergum IX with 18-31,24 setae ; laterosternite IX with 5-12,8 setae. Virga consisting of cluster of about 12 spines ; 53-64,59 $\mu \mathrm{m}$ long. Gonocoxite 330-431,380 $\mu \mathrm{m}$ long; inferior volsella very low; ending at $0.730 .82,0,77$ of gonocoxite length. Gonostylus $139-173,158 \mu \mathrm{m}$ long ; with large median projection, narrow apex and long and relatively low crista dorsalis ; megaseta $13-15,15 \mu \mathrm{m}$ long. HR 2.33-2.50,2.40; HV 2.08-2.69,2.43.

Female imago $(n=3$, except when otherwise stated)

Total length $3.85-3.92 \mathrm{~mm}$. Wing length 1.91 $1.98 \mathrm{~mm}$. Total length/wing length 1.98-2.00. Wing length/length of profemur 2.20-2.39. Coloration as in male or slightly more pale.

Head. AR 0.34-0.53. Lengths (in $\mu \mathrm{m}$ ) of flagellomeres : 113-128,56-71, 68-71, 64-88, 109-150. Longest sensilla chaetica on flagellomeres $30 \mu \mathrm{m}$ long. Pedicel bare. Temporal setae 34-36, including 27-30 inner verticals, 2-4 outer verticals, and 3 postorbitals. Clypeus with 20-23 setae. Tentorium 150-191 $\mu \mathrm{m}$ long, 26-34 $\mu \mathrm{m}$ wide. Stipes $134-165 \mu \mathrm{m}$ long, $75-83 \mu \mathrm{m}$ wide. Palp segments lengths (in $\mu \mathrm{m}): 38-41,45-49,90-101,83-86$ (2), 105-113 (2). Coronal suture absent or divided into two sutures 53-75 $\mu \mathrm{m}$ (2) and 9-38 (2) $\mu \mathrm{m}$ long.
Thorax. Antepronotum with 9-10 lateral setae. Dorsocentrals 36-47, acrostichals 24-27, prealars 20-24, supraalars 2-3, preepisternals absent. Scutellum with $32-36$ setae.

Wing (Fig. 4 E). VR 1.01-1.17. C extension 98-109 $\mu \mathrm{m}$ long. Brachiolum with 7-9 setae, $C$ extension with 5-8 non-marginal setae, $\mathrm{Sc}$ with 9-12, $\mathrm{R}$ with 31-35, $\mathrm{R}_{1}$ with 24-30, $\mathrm{R}_{4+5}$ with 22-31, RM and $M$ without, $M_{1+2}$ with $3-8, M_{3+4}$ with 56-69, $\mathrm{Cu}$ with 32-44, $\mathrm{Cu}_{1}$ with 33-39 (2), Pcu with 0-6, and An with 51-62 setae. Wing membrane with 9-36 setae in cell $\mathrm{m}$ basally of $\mathrm{RM}$, cell $\mathrm{r}_{4+5}$ with about 180-215, cell $\mathrm{m}_{1+2}$ with about $160-200$, cell $\mathrm{m}_{3+4}$ with 56-77 (2), cell cu $\mathrm{cu}_{1}$ with 6-44 (2), cell $\mathrm{m}_{3}+4$ with $56-77$ (2), cell pcu with $0-4$, and cell an with about 200-250 setae. Setae on axillary sclerite not observable. Squama with 7-10 setae.

Legs. Spur of front tibia $56 \mu \mathrm{m}$ long, spurs of middle tibia $41-45 \mu \mathrm{m}$ and $38 \mu \mathrm{m}$ long, of hind tibia 75-83 $\mu \mathrm{m}$ and $34-38 \mu \mathrm{m}$ long. Width at apex of front tibia $64-68 \mu \mathrm{m}$, of middle tibia $47-68 \mu \mathrm{m}$, of hind tibia $60-83 \mu \mathrm{m}$. Comb of 11-15 setae, longest seta 45-68 $\mu \mathrm{m}$ long, shortest seta 30-38 $\mu \mathrm{m}$ long. Tarsomere 1 of middle and hind leg with 2 pseudospurs each ; Tarsomere 2 of middle leg with 1-2 pseudospurs, of hind leg with 0-2 pseudospurs ; pseudospurs $26-38 \mu \mathrm{m}$ long. Lengths (in $\mu \mathrm{m}$ ) and proportions of legs :

\begin{tabular}{cccccccccccc}
\hline & $\mathrm{fe}$ & $\mathrm{ti}$ & $\mathrm{ta}_{1}$ & $\mathrm{ta}_{2}$ & $\mathrm{ta}_{3}$ & $\mathrm{ta}_{4}$ & $\mathrm{ta}_{5}$ & $\mathrm{LR}$ & $\mathrm{BV}$ & $\mathrm{SV}$ & $\mathrm{BR}$ \\
\hline $\mathrm{p}_{1}$ & $\mathbf{8 0 3 - 8 8 8}$ & $856-926$ & $468-520$ & $284-293$ & $208-227$ & $156-170$ & $113-132$ & $0.55-0.57$ & $2.77-2.92$ & $3.36-3.54$ & $1.5-2.0$ \\
$\mathrm{p}_{2}$ & $\mathbf{8 8 2 -} 936$ & $898-992$ & $350-378$ & $208-222$ & $161-170$ & $123-142$ & $113-118$ & $0.36-0.39$ & $3.31-3.64$ & $4.95-5.28$ & $1.5-1.8$ \\
$\mathrm{p}_{3}$ & $940-1030$ & $1162-1257$ & $567-624$ & $321-350$ & $274-284$ & $151-170$ & $113-128$ & $0.49-0.50$ & $3.07-3.21$ & $3.66-3.71$ & $2.0-2.2$ \\
\hline
\end{tabular}

Genitalia (Figs 3 D-G). Sternite VIII with 32-49 setae. Gonocoxite with knoblike, rounded apical projection, with 20-25 setae. Tergite IX (Figs $3 \mathrm{E}$, F), undivided to slightly divided, sometimes unsymmetrical with 29-43 setae. Segment $X$ with caudolateral, rounded projections. Cercus 143-146 $\mu \mathrm{m}$ long. Seminal capsule $165-188 \mu \mathrm{m}$, stronger sclerotized in apical 105-160 $\mu \mathrm{m}$ (2), 135-150 $\mu \mathrm{m}$ (2) long. Spermathecal ducts with small bulbs befor partially common opening. Notum 139-173 $\mu \mathrm{m}$ long.

\section{Remarks}

The wing chaetotaxy, especially the number of setae in cells $r_{4+5}, m_{1+2}$ and $m_{3+4}$ is very variable in the species. Also the thoracic chaetotaxy is quite variable with for instance 2-12 antepronotal setae. However, this can be expected in an abberrant species with adaptions to ground mating. 


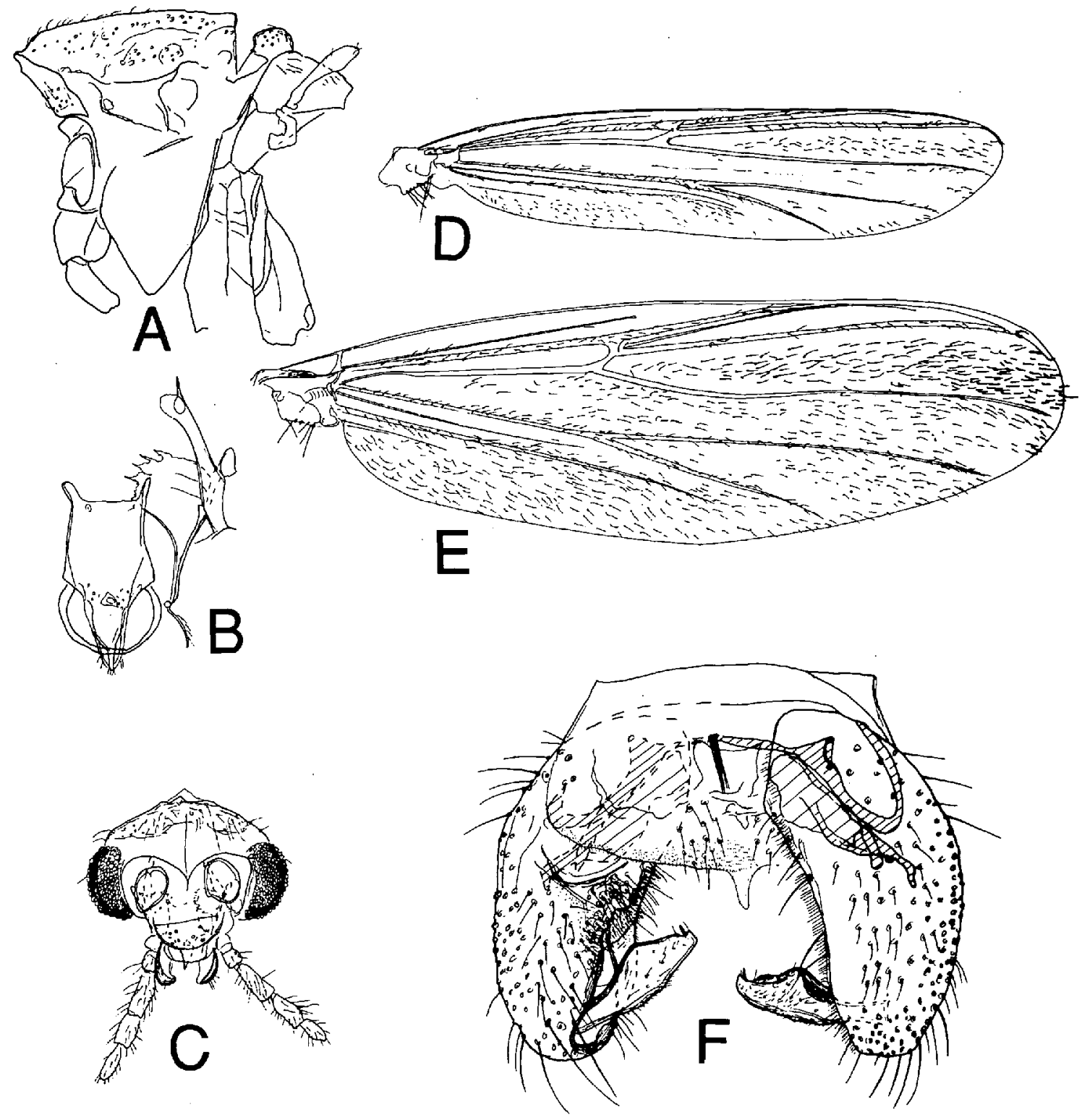

Fig. 4. Metriocnemus sibiricus (Lundström), imago : A. Male thorax ; B. Tentorium, stipes and cibarial pump of male ; C. Head of male ; D. Wing of male ; E. Wing of female ; F. Male hypopygium.

Fig. 4. Metriocnemus sibiricus (Lundström), imago : A. Thorax mâle ; B. Tentorium, stipes et pompe cibariale de mâle ; C. Tête de mâle ; D. Aile de mâle ; E. Aile de femelle ; F. Hypopyge mâle. 
Metriocnemus caudigus sp. n. (Fig. 5 A, B)

Type material : Holotype $\sigma$, Norway: Nord Trøndelag, Høylandet, Skiftesåa, 18.VI.1986, K. Aagaard (ZMB No. 147). Paratype $\sigma$ as holotype (KA) ; Hordaland, Bergen, at Skomakerdiket, $1 \circ^{\circ}$, 17.VI.1987, A. Fjeldså (ZMB).

Diagnostic characters : The male imago is easily separable from other members of the eurynotus group by means of the slender gonostylus with the long and low crista dorsalis, the robust and long anal point, and an AR of 1.3-1.5.

Male imago ( $n=3$ except when otherwise stated)

Total length $2.51-3.13 \mathrm{~mm}$. Wing length 1.50-1.77 $\mathrm{m}$. Total length/wing length 1.67-1.78. Wing length/length of profemur 2.43-2.53. Coloration brown, haltere pale brown, squama brown, rest of wing nearly transparent.

Head. AR 1.29-1.53. Ultimate flagellomere $425-520 \mu \mathrm{m}$ long. Temporal setae $21-27$, including 11-17 inner verticals, $4-5$ outer verticals, and 5-6 postorbitals. Clypeus with 25 setae. Tentorium 154-161 $\mu \mathrm{m}$ long, 34-47 $\mu \mathrm{m}$ wide. Stipes 131-150 $\mu \mathrm{m}$ long, 68-75 $\mu \mathrm{m}$ wide. Palp segments lengths (in $\mu \mathrm{m}$, $\mathrm{n}=23$ ) : 34-41, 41-64, 135-169, 113-116, 128-129.

Thorax. Antepronotum with 9-19 setae. Dorsocentrals 54-61, acrostichals $38-40$, prealars $34-38$, supraalars 3. Scutellum with $29-40$ setae.

Wing. VR 1.19-1.25. C extension 75-106 $\mu \mathrm{m}$ long. Brachiolum with 5-7 setae, $C$ extension with 12-21 non-marginal setae, Sc with 22-39, R with 48-56, $\mathrm{R}_{1}$ with 38-55, $R_{4+5}$ with 63-92, $R M$ with 4-7, $M$ with 8-24, $\mathrm{M}_{1+2}$ with $78-82, \mathrm{M}_{3+4}$ with 35-53, Cu with 42-54, $\mathrm{Cu}_{1}$ with 25-34, Pcu with 58-77, An with 40-52 setae. Wing membrane with setae covering most cells, with 33-56 setae in cell m basally of RM. Axillary sclerite with 4 setae. Squama with $18-23$ setae, $45-176 \mu \mathrm{m}$ long.

Legs. Spur of front tibia $64-83 \mu \mathrm{m}$ long, spurs of middle tibia $34-41 \mu \mathrm{m}$ and 30-39 $\mu \mathrm{m}$ long; of hind tibia 64-84 $\mu \mathrm{m}$ and 30-36 $\mu \mathrm{m}$ long. Width at apex of front tibia 38-49 $\mu \mathrm{m}$, of middle tibia $45-49 \mu \mathrm{m}$, of hind tibia $56-64 \mu \mathrm{m}$. Comb of 10-12 setae, 30-64 $\mu \mathrm{m}$ long. Tarsomere 1 of middle and hind leg and $\mathrm{ta}_{2}$ of middle leg each with 2 pseudospurs, 23-38 $\mu \mathrm{m}$ long. Lengths (in $\mu \mathrm{m}$ ) and proportions of legs $\left(\mathrm{n}=2-3\right.$ on $\left.\mathrm{ta}_{1}-\mathrm{ta}_{5}\right)$ :

\begin{tabular}{|c|c|c|c|c|c|c|c|c|c|c|c|}
\hline & fe & $\mathrm{ti}$ & $\operatorname{ta}_{1}$ & $\mathrm{ta}_{2}$ & $\mathrm{ta}_{3}$ & $\mathrm{ta}_{4}$ & $\mathrm{ta}_{5}$ & LR & BV. & SV & $\operatorname{BR}(n=1)$ \\
\hline$p_{1}$ & 614-699 & $756-926$ & $387-435$ & 246-279 & 175-189 & $113-128$ & 76 & $0.51-0.52$ & $2.86-2.88$ & $3.41-3.54$ & 2.5 \\
\hline$p_{2}$ & $662-779$ & $756-851$ & $293-340$ & $161-198$ & $125-156$ & $76-109$ & $66-85$ & $0.39-0.40$ & $3.59-4.02$ & $4.74-4.84$ & 2.5 \\
\hline$p_{3}$ & $662-803$ & $936-1153$ & $406-491$ & $217-246$ & 184-198 & $99-113$ & $71-76$ & $0.43-0.45$ & $3.46-3.50$ & $3.82-3.98$ & 4.1 \\
\hline
\end{tabular}

Hypopygium (Fig. 5 A, B). Anal point proper 49-68 $\mu \mathrm{m}$ long, $38-60 \mu \mathrm{m}$ wide at base, $8-11 \mu \mathrm{m}$ wide at apex ; with 21-28 setae at base on tergite IX ; laterosternite IX with 3-6 setae. Phallapodeme 98-116 $\mu \mathrm{m}$ long, transverse sternapodeme $105 \mu \mathrm{m}$ long. Virga 53-56 $\mu \mathrm{m}$ long, consisting of cluster of about 10 spines. Gonocoxite $214-236 \mu \mathrm{m}$ long, inferior volsella low, ending at $0.70-0.75$ gonocoxites length. Gonostylus $116-120 \mu \mathrm{m}$ long, parallel-sided, with long and low crista dorsalis; megaseta 11-17 $\mu \mathrm{m}$ long. HR 1.84-1.97, HV 2.17-2.74.

Metriocnemus intergerivus sp. n. (Fig. 5 C-F)

Type material : Holotype $\sigma$, Canada : Manitoba, Lake Winnipeg, 2 mi. off Grand Rapids, 13.VII.1969, S.S. Chang (ZMB No. 148). Para- types : $1 \sigma^{\prime}$ as holotype ; $2 \sigma^{*}$ as holotype except Pine Dock 10.VIII.1969; $1 \sigma^{\circ}$ as holotype except 6 1/2 mi.off Sturgeonskin Pt. 14.VIII.1969; 5 o, $2 \%$, as holotype except $11 / 4 \mathrm{mi}$.off McCreary Island 15.VIII.1969; 1 o as holotype except Gull Harbour 15.VIII.1969; $1 \sigma^{*}$ as holotype except Government Dock, Victoria Beach 25.VIII.1969 ; $1 \sigma$ as holotype except $21 / 2 \mathrm{mi}$. offshore Horse Island 29.VIII.1969; 1 o except 20 mile Creek 26.VIII.1971, E. Johnson and M. Roberts. Other material : Norway, Nordland, Bodø, Isvik, $1 \sigma^{\circ}$, 8.VII.1982, A. Fjeldså (ZMB).

Diagnostic characters : The male imago combines the well developed virga of the eurynotus group with the low crista dorsalis, weak anal point, and 


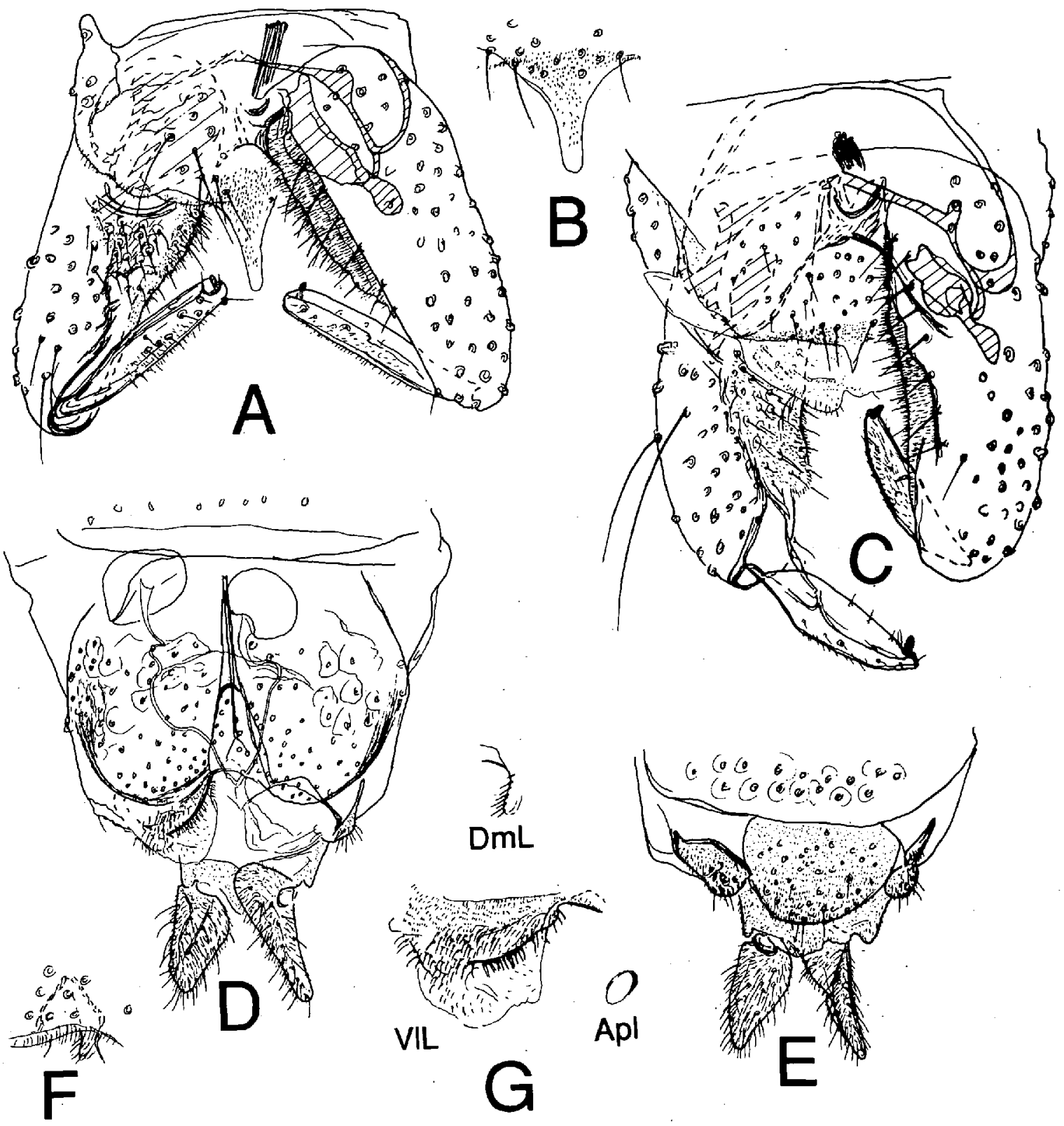

Fig. 5. Metriocnemus spp., imagines : A-B. M. caudigus sp. n., male ; hypopygium of holotype (A), anal point of paratype (B) ; C-G. M. intergerivus sp. n. ; C. male hypopygium ; D-G. Female genitalia, ventral view (D), dorsal view (E), ventrolateral view of floor (F), lobes of gonapophyses (G). (Dml, dorsomesal lobe ; VIL, ventrolateral lobe ; ApL, apodeme lobe).

Fig. 5. Metriocnemus spp., imagos : A-B. M. caudigus n. sp., mâle : hypopyge de l'holotype (A), pointe anale du paratype (B) ; C-G. M. intergerivus n. sp. : C. hypopyge mâle ; D-G. Genitalia femelle, vue ventrale (D), vue dorsale (E), vue ventrolatérale du plancher (F), lobes des gonapophyses (G). (Dml, lobe dorsomésal ; VIL, lobe ventrolatéral ; Apl, lobe apodème). 
low inferior volsella with apical low bulge typical of the fuscipes group. The AR is 2.0-2.4. The female imago has rounded tergite IX ; small gonocoxite IX without apicomedian projection, with $9-10$ setae ; sternite VIII forming floor under vagina and cercus shorter than notum.

Male imago $(\mathrm{n}=10-13)$

Total length $2.91-3.75,3.46 \mathrm{~mm}$. Wing length 1.85-2.19,2.00. Total length/wing length 1.57-1.85,1.74. Wing length/length of profemur 2.41-2.64,2.48. Coloration brownish black including scutellum, haltere brown.

Head. AR 2.04-2.38,2.17. Ultimate flagellomere 643-747,692 $\mu \mathrm{m}$ long. Temporal setae 29-47,37; including 8-22,14 inner verticals ; 9-21,14 outer verticals; and 6-16,9 postorbitals. Clypeus with 29-52,42 setae. Tentorium 134-170,150 $\mu \mathrm{m}$ long ; 41-49,44 $\mu \mathrm{m}$ wide. Palp segments lengths (in $\mu \mathrm{m}$ ) : $28-37,32$; 48-63,53 ; 196-243,226 ; 133-167,150 ; 167-196,182. Third palpal segement with 2 lanceolate sensilla clavata.

Thorax. Antepronotum with 14-22,18 setae. Dorsocentrals 59-78,66 ; acrostichals 21-30,25 ; prealars
54-73,62 ; supraalars $3-5,4$. Scutellum with $39-45,42$ setae.

Wing. VR 1.18-1:24,1.21. C extension $48-82,68 \mu \mathrm{m}$ long. Brachiolum with $10-15,13$ setae ; C extension with 12-18,15 non-marginal setae ; Sc with 7-24,14 ; $\mathrm{R}$ with $52-73,63 ; \mathrm{R}_{1}$ with $42-58,50 ; \mathbf{R}_{4+5}$ with 56-80,66 ; RM With $1-7,4$; $M$ with $20-31,23$; $\mathrm{M}_{1+2}$ with 53-106,71; $\mathrm{M}_{3+4}$ with $37-52,44 ; \mathrm{Cu}$ with $36-51,40 ; \mathrm{Cu}_{1}$ with 20-33,26; Pcu with 2472,44 ; and An with 24-72,44 setae. Wing membrane with setae covering most cells ; with 24-65, 40 setae in cell $\mathrm{m}$ basally of RM. Axillary sclerite with 4-7,6 setae. Squama with 43-64,53 setae ; longest seta $173-244,214 \mu \mathrm{m}$ long; shortest seta 49-94,58 $\mu \mathrm{m}$ long.

Legs. Spur of front tibia $78-92,85 \mu \mathrm{m}$ long ; spurs of middle tibia $35-43,39 \mu \mathrm{m}$ and 32-41,37 $\mu \mathrm{m}$ long ; of hind tibia $78-94,84 \mu \mathrm{m}$ and $32-43,37 \mu \mathrm{m}$ long. Width at apex of front and middle tibia 46$53,50 \mu \mathrm{m}$; of hind tibia 57-68,62 $\mu \mathrm{m}$. Comb with 9-12,11 setae ; longest seta $45-63,55 \mu \mathrm{m}$; shortest seta $22-32,27 \mu \mathrm{m}$ long. Tarsomeres 1 and 2 of middle and hind legs each with 2 pseudospurs ; 22-49,29 $\mu \mathrm{m}$ long. Lengths (in $\mu \mathrm{m}$ ) and proportions of legs :

\begin{tabular}{|c|c|c|c|c|c|c|c|c|c|c|c|}
\hline & $\mathrm{fe}$ & $\mathrm{ti}$ & $\mathrm{ta}_{1}$ & $\mathrm{ta}_{2}$ & $\mathrm{ta}_{3}$ & $\mathrm{ta}_{4}$ & $\mathrm{ta}_{5}$ & LR & BV & SV & BR \\
\hline$p_{1}$ & $756-866,803$ & $857-1009,950$ & $524-605-568$ & $330-334,350$ & $213-253-230$ & $133-160,146$ & $87-107,97$ & $0,59-0.61,0.60$ & $2.72-2.95,2,83$ & $3.03-3.13,3.08$ & $3.0-3.5,3.2$ \\
\hline$p_{2}$ & $807-908,865$ & $840-1067,943$ & $326-401,361$ & $196-231,214$ & $146-173,159$ & $103-127,114$ & $85-103,93$ & $0.37-0.40,0.38$ & $3.56-3.96,3.75$ & $4.88-5.18,5.02$ & $3.5-4.8,4.1$ \\
\hline$p_{3}$ & $857-992,923$ & $1148-1294,1204$ & $469-585,523$ & $283-367,306$ & $220-256,237$ & $130-160,145$ & $90-120,107$ & $0.41-0.46,0.44$ & $3.06-3.46,3.54$ & $3.90-4,26,4.07$ & $5.3-8.7,6.9$ \\
\hline
\end{tabular}

Hypopygium (Fig. 5 C). Anal point proper 15-26,22 $\mu \mathrm{m}$ long; weak and tapering; with 44-65,56 strong setae at base on tergite IX ; laterosternite IX with 7-12,10 setae. Phallapodeme 100-117,107 $\mu \mathrm{m}$ long ; apodeme lobe well sclerotized ; transverse sternapodeme 102-129,111 $\mu \mathrm{m}$ long with well developed, knob-like oral projections. Virga 19-26,23 $\mu \mathrm{m}$ long ; consisting of about 14 spines. Gonocoxite $193-250,228 \mu \mathrm{m}$ long : intergonocoxal plate conspicuous, well sclerotized ; inferior

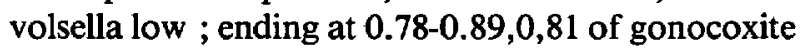
length, with slight apical hump. Gonostylus 95-112,103 $\mu \mathrm{m}$ long; narrow with low and long crista dorsalis ; megaseta $8-15,12 \mu \mathrm{m}$ long. HR 1.93-2.38,2.21; HV 3.06-3.69,3.31.
Female imago $(n=2)$

Total length $2.64-3.23 \mathrm{~mm}$. Wing length 1.36-1.78 mm. Total length/wing length 1.81-1.91. Wing length/length of profemur 2.65-2.82. Coloration slightly more pale than in male.

Head. AR 0.24-0.27. Lengths (in $\mu \mathrm{m}$ ) of flagellomeres : 96-113, 60-75, 56-75, 60-71, 71-94. Longest sensilla chaetica on flagellomeres $60-66 \mu \mathrm{m}$ long. Temporal setae 40-49, including 28-36 inner verticals, 12 outer verticals, and 1-2 postorbitals. Clypeus with 29-34 setae. Tentorium $143 \mu \mathrm{m}$ long, 24-26 $\mu \mathrm{m}$ wide. Stipes 139-153 $\mu \mathrm{m}$ long, 45-56 $\mu \mathrm{m}$ wide. Palp segments lengths (in $\mu \mathrm{m}$ ) : 96-113, 60-75, 56-75, 60-71, 71-94. Coronal suture absent. 
Thorax. Antepronotum with 10-23 setae. Dorsocentrals 72 including 30-40 on humeral area, acrostichals 28 , prealars $44-107$, supraalars $3-4$. Scutellum with 35 setae.

Wing. VR 1.21-1.23. C extension 67-83 $\mu \mathrm{m}$ long. Brachiolum with 8-12 setae, $C$ extension with 16-19 non-marginal setae, $S c$ with $20-46$, $R$ with $65-72, R_{1}$ with $67-80, \mathbf{R}_{2+3}$ with $4-10, \mathbf{R}_{4+5}$ with $111-117$,
RM with 8, M with 25-43, $\mathrm{M}_{1+2}$ with 80-99, $\mathrm{M}_{3+4}$ with 40-42, Cu with 36-45, $\mathrm{Cu}_{1}$ with $23-37$, Pcu with 53-81, An with 31-71 setae. Wing membrane with setae in most cells, with $56-113$ setae in cell $\mathrm{m}$ basally of RM. Squama with 21-32 setae.

Legs. Spurs, tibia width, comb and pseudospurs as in male. Lengths (in $\mu \mathrm{m}$ ) and proportions of legs :

\begin{tabular}{cccccccccccc}
\hline & $\mathrm{fe}$ & $\mathrm{ti}$ & $\mathrm{ta}_{1}$ & $\mathrm{ta}_{2}$ & $\mathrm{ta}_{3}$ & $\mathrm{ta}_{4}$ & $\mathrm{ta}_{5}$ & $\mathrm{LR}$ & $\mathrm{BV}$ & $\mathrm{SV}$ & $\mathrm{BR}$ \\
\hline $\mathrm{p}_{1}$ & $483-672$ & $592-773$ & $350-483$ & $243-306$ & $157-190$ & $93-123$ & $70-90$ & $0.59-0.62$ & $2.53-2.72$ & $2.99-3.07$ & $2.8-2.9$ \\
$\mathrm{p}_{2}$ & $592-773$ & $639-857$ & $240-326$ & $147-190$ & $103-143$ & $65-97$ & $57-80$ & $0.38-0.39$ & $3.84-3.95$ & $5.03-5.13$ & $2.8-3.6$ \\
$\mathrm{p}_{3}$ & $632-866$ & $798-1059$ & $377-483$ & $216-279$ & $183-240$ & $89-133$ & $75-97$ & $0.46-0.47$ & 3.21 & $3.79-3.99$ & 5.1 \\
\hline
\end{tabular}

Genitalia (Figs 5 D-G). Sternite VIII forming small to large floor under vagina (Fig. $5 \mathrm{~F}$ ) with about 80-110 setae. Gonocoxite relatively small, without projection, with 9-10 setae. Tergite IX (Fig. 5 E) rounded, undivided, with 58 setae. Cercus 133-143 $\mu \mathrm{m}$ long. Seminal capsule 71-75 $\mu \mathrm{m}$ long inclusive neck and equally wide. Notum $153-167 \mu \mathrm{m}$ long.

\section{Remarks}

Apart from the presence of a well developed virga this species looks similar to species of the fuscipes group. The specimen from Norway is not included in the type material as the antenna is broken and there are only 29 setae on tergite IX. In other details, however, the specimen fits the description.

\section{Metriocnemus aculeatus Chaudhuri et Bhattacharyay} (Fig. 6 A)

Metriocnemus aculeatus Chaudhuri et Bhattacharyay, in Chaudhuri, Bhattacharyay \& Dutta $1989: 309$.

Material examined : China : Sichuan, Mt Jinfo, $10 *$ 9.V.1986, X. Wang (XW). Since the Chinese specimen in several aspects differs from the description by Chaudhuri et al. (1989) it is described below.

Male imago $(n=1)$

Total length $3.37 \mathrm{~mm}$. Wing length $2.07 \mathrm{~mm}$.
Total length/wing length 1.63 . Wing length/length of profemur 2.29. Coloration blackish brown.

Head. AR 1.62. Ultimate flagellomere $643 \mu \mathrm{m}$ long. Temporal setae 13 , including 5 inner verticals, 6 outer verticals and 2 postorbitals. Clypeus with 12 setae. Tentorium $150 \mu \mathrm{m}$ long, $38 \mu \mathrm{m}$ wide. Stipes $135 \mu \mathrm{m}$ long, $64 \mu \mathrm{m}$ wide. Palp segments lengths (in $\mu \mathrm{m}$ ) : 38, 41, 161, 128, 161. Third palpal segment with 1 apical lanceolate sensillum clavatum.

Thorax. Antepronotum with 4 setae. Dorsocentrals 22 , acrostichals about 20 , prealars 13 , supraalar 1. Scutellum with 12 setae.

Wing. VR 1.17. C extension $128 \mu \mathrm{m}$ long. Brachiolum with 5 setae ; $C$ extension with 20 nonmarginal setae ; Sc, RM, M and Pcu without setae ; $R$ with 26 setae ; $R_{1}$ with $20 ; R_{4+5}$ with $37 ; M_{1+2}$ with $56 ; \mathrm{M}_{4+5}$ with 38 ; $\mathrm{Cu}$ with $11 ; \mathrm{Cu}_{1}$ with 21 ; and An with 25 setae. Wing membrane with about 80 setae in cell an ; without setae in cell $\mathrm{m}$ basally of RM and on anal lobe. Squama with 9 setae.

Legs. Spur of front tibia $86 \mu \mathrm{m}$ long, spurs of middle tibia $34 \mu \mathrm{m}$ and $30 \mu \mathrm{m}$ long, of hind tibia $64 \mu \mathrm{m}$ and $34 \mu \mathrm{m}$ long. Comb of 13 setae, 23-56 $\mu \mathrm{m}$ long. Tarsomeres 1-3 of middle and hind legs each with apparently only 1 pseudospur, 21-26 $\mu \mathrm{m}$ long. Lengths (in $\mu \mathrm{m}$ ) and proportions of legs :

\begin{tabular}{|c|c|c|c|c|c|c|c|c|c|c|c|}
\hline & $\mathrm{fe}$ & ti & $\mathrm{ta}_{1}$ & $\mathrm{ta}_{2}$ & $\mathrm{ta}_{3}$ & $\mathrm{ta}_{4}$ & $\operatorname{ta}_{5}$ & LR & BV & SV & BR \\
\hline $\mathrm{p}_{1}$ & 902 & 992 & - & - & - & - & - & - & - & - & - \\
\hline $\mathrm{p}_{2}$ & 907 & 879 & 501 & 232 & 175 & 104 & 71 & 0.57 & 3.94 & 3.57 & 3.0 \\
\hline$p_{3}$ & 973 & 1096 & 647 & 312 & 236 & 123 & 80 & 0.59 & 3.59 & 3.20 & 3.7 \\
\hline
\end{tabular}


Hypopygium (Fig. $6 \mathrm{~A}$; Chaudhuri et al. 1989, Fig. $1 \mathrm{~d}$ ). Anal point proper $58 \mu \mathrm{m}$ long, tapering to sharp point, with 15 setae at base on tergite IX ; laterosternite IX with 7 setae. Phallapodeme $98 \mu \mathrm{m}$ long, transverse sternapodeme $113 \mu \mathrm{m}$ long. Virga very weak, consisting of 10 about $11 \mu \mathrm{m}$ long, parallel and not clustered spines. Gonocoxite $218 \mu \mathrm{m}$ long, inferior volsella low ending at 0.80 of gonocoxite length, but with a distinct notch at 0.56 . Gonostylus $103 \mu \mathrm{m}$ long, crista dorsalis apparently absent, megaseta $11 \mu \mathrm{m}$ long. HR 2.11, HV 3.28.

\section{Remarks}

The Chinese specimen has a much higher antennal ratio (1.62) than the Indian specimens (1.09). Most of the other differences most likely are due to measurements on not well cleared specimens or miscalculations on the Indian specimens. There are for instance no species of Metriocnemus where the fourth palpal segment is not twice as long as the third, no species without antepronotal setae and no species with a comb of $3-15 \mu \mathrm{m}$ long setae, all said to be characteristics of the Indian specimens. The SV of the Indian specimens are wrongly calculated. The corrected ones are similar to those of the Chinese specimen. Tergite IX is said to have 48-50 setae while the drawing shows 13 . The spines of the virga are easily overlooked. They were observed in the Chinese specimen first when the specimen was better cleared and remounted.

The wing chaetotaxy, the very high leg ratio of the middle leg compared to the hind leg, and the characteristic hypopygium with a very long, sharply pointed anal point and lacking crista dorsalis make a conspecificity of the Indian and Chinese specimens almost certain. However, $M$. aculeatus differs from all other Metriocnemus in the shape of the virga and in the apparent total absence of a crista dorsalis and may conceivably not belong in the genus.

\subsection{The fuscipes group}

Metriocnemus unilinearis Chaudhuri et Bhattacharyay (Fig. 6 B)

Metriocnemus unilinearis Chaudhuri et Bhattacharyay, in Chaudhuri, Bhattacharyay \& Dutta $1989: 312$.

Material examined : China : Tibet, Zhangmu, 1 o , 7.IX.1987, C. Deng (XW).
Male imago $(\mathrm{n}=1)$

As in Chaudhuri et al. (1989: 312) with the following exceptions and additions : Size slightly smaller (total length $2.40 \mathrm{~mm}$, wing length $1.42 \mathrm{~mm}$ ).

Head. AR. 0.68. Ultimate flagellomere $274 \mu \mathrm{m}$ long, pointed, with stiff preapical seta and unusually weak sensilla chaetica at apex.

Thorax. Antepronotum with 1 seta. Dorsocentrals 12 , acrostichals about 15,1 supraalar.

Wing. Brachiolum with 2 setae, $C$ extension with 14 non-marginal setae, Sc with 9 setae, $R$ with 23 , $R_{1}$ with $28, R_{4+5}$ with 36 setae, $R M$ bare, $M$ with 1 seta, $M_{1+2}$ with 54 setae, $M_{3+4}$ with 28 , Cu with $23, \mathrm{Cu}_{1}$ with 19 , Pcu with 31 , and An with 34 setae. Wing membrane with relatively sparse setae in most cells, with 20 setae in cell $\mathrm{m}$ basally of RM.

Legs. Tarsomeres 1 and 2 of middle and hind leg each with apparently only 1 pseudospur, $19-23 \mu \mathrm{m}$ long.

Hypopygium (Fig. 6 B ; Chaudhuri et al. 1989, Fig. $4 \mathrm{~d}$ ). Anal point proper $56 \mu \mathrm{m}$ long, sharply pointed, with 13 setae at base on tergite IX, laterosternite IX with 5 setae. Phallapodeme $86 \mu \mathrm{m}$ long, transverse sternapodeme $83 \mu \mathrm{m}$ long. Virga absent: Gonocoxite $188 \mu \mathrm{m}$ long, inferior volsella low ending at 0.59 gonocoxite length. Gonostylus $94 \mu \mathrm{m}$ long, with long and low crista dorsalis, megaseta $13 \mu \mathrm{m}$ long. HR 2.00, HV 2.55.

\section{Remarks}

The Tibetan specimen has a lower antennal ratio (0.68) than the Indian specimens (1.03). As for $M$. aculeatus there are some mistakes in the description by Chaudhuri et al. ; the SV are wrongly calculated and should be $S V_{1} 2.33, S_{2} 4.11$ and $S_{3} 3.58$ which are only slightly higher than in the Chinese specimen ; tergite IX has about 11 setae according to Fig. $4 \mathrm{~d}$ in Chaudhuri et al. while the text states $75-80$ setae ; and only the basal, well sclerotized part of the phallapodeme apparently is measured.

\section{Metriocnemus exilacies sp. n. (Fig. 6 C)}

Type material : Holotype o", Norway : NordTrøndelag, Høylandet, Skiftesåa, 15.VIII.1988, K. Aagaard (ZMB No. 149). Paratype $1 \sigma^{\circ}$, as holotype (KA).

Diagnostic characters : The male imago can be separated from other species of the fuscipes group 

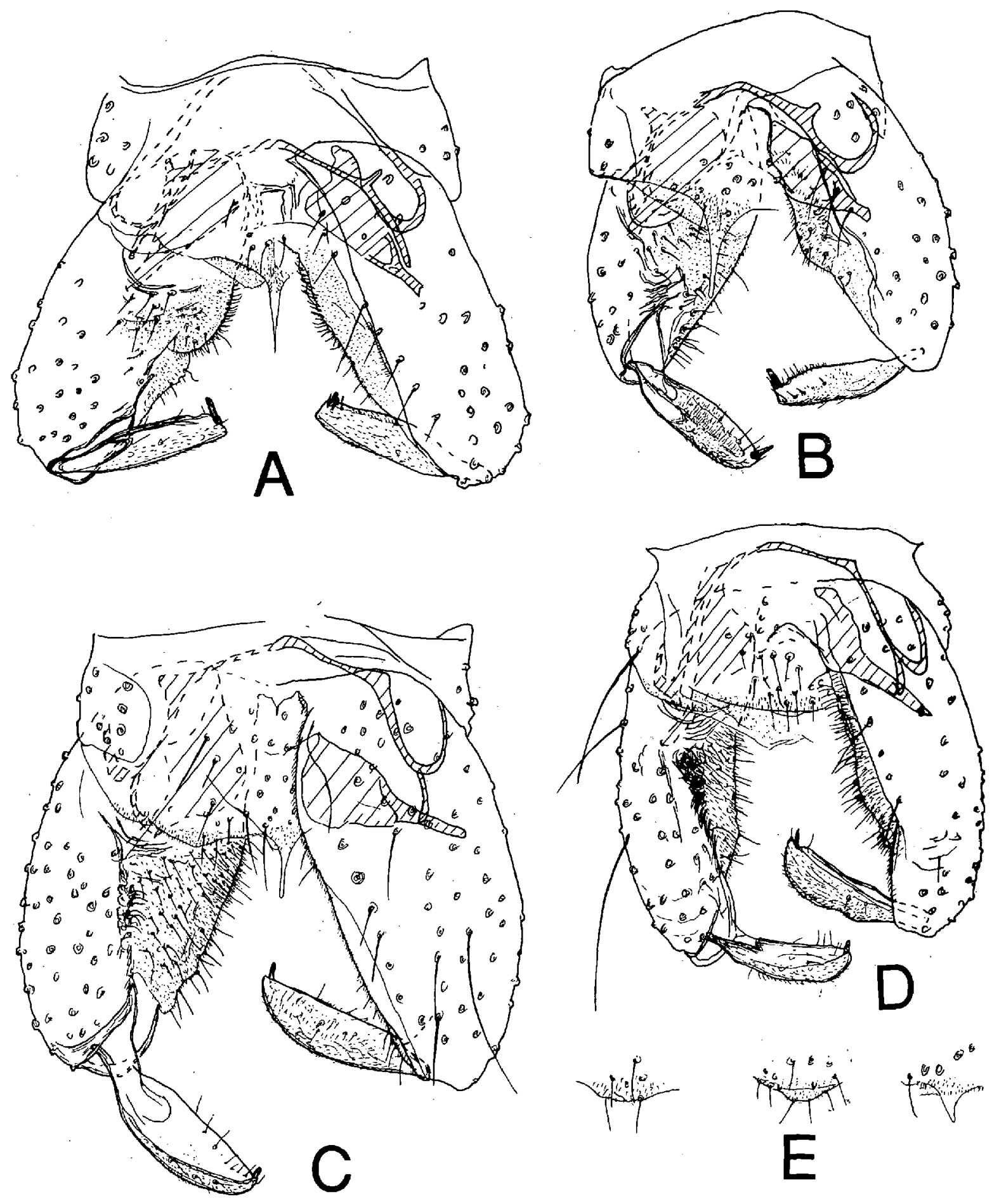

Fig. 6. Metriocnemus spp., male imagines, hypopygia : A. M. aculeatus Chaudhuri et Bhattacharyay ; B. M. unilinearis Chaudhuri et Bhattacharyay ; C. M. exilacies sp. n. ; D, E. M. beringiensis (Cranston et Oliver), holotype (D), variations in anal point of specimens from Høylandet, Norway (E).

Fig. 6. Metriocnemus spp., imagos mâle, hypopyge : A. M. aculeatus Chaudhuri et Bhattacharyay ; B. M. unilinearis Chaudhuri et Bhattacharyay ; C. M. exilacies n. sp. ; D, E. M. beringiensis (Cranston et Oliver), holotype (D), variations de la pointe anale de spécimens d'Høylandet, Norvège (E). 
by the parallel-sided apical portion of the anal point and by having $0-3$ setae on vein $M$ combined with 23-40 setae on subcosta.

Male imago $(n=1-2)$

Total length $3.82-3.95 \mathrm{~mm}$. Wing length 2.53-2.64 mm. Total length/wing length 1.50-1.51. Wing length/length of profemur 2.38-2.48. Coloration brown with darker vittae and markings, scutellum more pale, haltere pale brown.

Head. Antenna lost. Temporal setae 31, including 17 inner verticals, 9-11 outer verticals and 1-3 postorbitals. Clypeus with 16-18 setae. Tentorium 158-176 $\mu \mathrm{m}$ long, 53-60 $\mu \mathrm{m}$ wide. Stipes $150-154 \mu \mathrm{m}$ long, $53 \mu \mathrm{m}$ wide. Palp segments lengths (in $\mu \mathrm{m}$ ) : $38-45,49-60,221-236,150-165,191-206$. Third palpal segment with 2 lanceolate sensilla clavata.

Thorax. Antepronotum with 8-10 setae. Dorsocentrals 33, acrostichals 33-42, prealars 18-26, supraalars 2-3. Scutellum with 24-25 setae.
Wing. VR 1.24-1.27. C extension $173 \mu \mathrm{m}$ long. Brachiolum with 8 setae, $C$ extension with 24-26 non-marginal setae, $\mathrm{Sc}$ with 23-40, $\mathrm{R}$ with 55-65, $\mathrm{R}_{1}$ $32-42, R_{4+5}$ with 58-72, $R M$ with $0-3, M$ with $0-3$, $\mathrm{M}_{1+2}$ with $56, \mathrm{M}_{3+4}$ with $39-50$, $\mathrm{Cu}$ with $31-36$, $\mathrm{Cu}_{1}$ with 26-34, Pcu with 50-53, and An with 56-74 setae. Wing membrane with setae covering most cells, with 36-42 setae in cell $\mathrm{m}$ basally of RM. Axillary sclerite with 6-7 setae. Squama with 24-26 setae, longest seta $244-263 \mu \mathrm{m}$ long, shortest seta $64-83 \mu \mathrm{m}$ long.

Legs. Spur of front tibia $75 \mu \mathrm{m}$ long, spurs of middle tibia $41-45 \mu \mathrm{m}$ and 39-41 $\mu \mathrm{m}$ long, of hind tibia $79-86 \mu \mathrm{m}$ and $47-49 \mu \mathrm{m}$. Width at apex of front and middle tibia $53-55 \mu \mathrm{m}$, of hind tibia $64 \mu \mathrm{m}$. Comb with $12-14$ setae, $28-60 \mu \mathrm{m}$ long. Tarsomeres 1 and 2 of middle and hind tibia each with 2 pseudospurs 26-39 $\mu \mathrm{m}$ long. Lengths (in $\mu \mathrm{m}$ ) and proportions of legs.:

\begin{tabular}{lccccccccccc}
\hline & $\mathrm{fe}$ & $\mathrm{ti}$ & $\mathrm{ta}_{1}$ & \multicolumn{1}{c}{$\mathrm{ta}_{2}$} & $\mathrm{ta}_{3}$ & \multicolumn{1}{c}{$\mathrm{ta}_{4}$} & $\mathrm{ta}_{5}$ & $\mathrm{LR}$ & $\mathrm{BV}$ & $\mathrm{SV}$ & $\mathrm{BR}$ \\
\hline $\mathrm{p}_{1}$ & $1058-1063$ & $1266-1285$ & 794 & 491 & 331 & 208 & 123 & 0.63 & 2.71 & 2.93 & 3.1 \\
$\mathrm{p}_{2}$ & $1068-1087$ & $1162-1200$ & $501-510$ & $307-321$ & 227 & $142-151$ & 113 & 0.43 & $3.36-3.54$ & $4.45-4.48$ & $3.5-4.1$ \\
$\mathrm{p}_{3}$ & $1195-1200$ & $1512-1531$ & 680 & 425 & 321 & 198 & 113 & 0.45 & 3.20 & 3.98 & 4.0 \\
\hline
\end{tabular}

Hypopygium (Fig. $6 \mathrm{C}$ ). Anal point proper 53-56 $\mu \mathrm{m}$ long, tapering in basal half, nearly parallel-sided in apical half, with $34-42$ at base on tergite IX ; laterosternite IX with 12 setae. Phallapodeme 131-135 $\mu \mathrm{m}$ long ; transverse sternapodeme $120-135 \mu \mathrm{m}$ long, with low oral projections. Virga absent. Gonocoxite 285-289 $\mu \mathrm{m}$ long ; inferior volsella low, ending at $0.81-0.82$ of gonocoxite length. Gonostylus $129-143 \mu \mathrm{m}$ long, with low crista dorsalis ; megaseta 13-15 $\mu \mathrm{m}$ long. HR 2.03-2.20, HV 2.67-3.06.

\section{Remarks}

Although the antennae are lost in the described specimens, the anal point and the unusual combination of few or no setae on $M$ with numerous setae on the subcosta makes the species easily recognizable.

\section{Metriocnemus fuscipes (Meigen)}

New material examined : Norway : Oppland, Dovre, Atnaelv, Skranglehaugane, Malaise trap, 2 ơ, 8 \& 18.VII.1986, K. Aagaard (KA) ; Hedmark, Storelvdal, Atnaelv, Solbakken, Malaise trap, $1 \%$, 2.VIII.1986, K. Aagaard (KA), Møre \& Romsdal, Volda, Litlebøvatn, 1 o $^{\circ}, 26$. VII.1986, $\emptyset$ A. Schnell (ZMB). China : Ningxia, Liupan Mt, 1 o , 4.VIII.1987, W. Wang (XW).

One of the Norwegian specimens has a slightly lower AR of 0.81 than that reported in Sæether (1989a, AR 0.86-1.17), and the Chinese specimen has a slightly higher AR of about 1.28. Another Norwegian specimen has slightly more numerous setae on the veins with 70 setae on Sc, 47 on $M$ and 63 on $\mathrm{Cu}$.

The species was previously known from all over Europe, and the Nearctic Region, from East Siberia, 
Canary Islands, the Azores and Madeira. Although most Metriocnemus identifications are in need of confirmation, the low leg ratio of the hind leg make this species easily recognizable.

\section{Metriocnemus beringiensis (Cranston et Oliver)}

(Fig. 6 D, E)

Apometriocnemus beringiensis Cranston \& Oliver $1988: 428$.

Metriocnemus beringiensis (Cranston \& Oliver) ; Sæther in Cranston et al. $1989: 178,213$.

Type material : Holotype on: Canada : Yukon Territory, Trout Lake, 9.VIII.1984, D.R. Oliver (CNC No. 19684).

New material examined : Norway: NordTrøndelag, Høylandet, Skiftesåa, $6 \sigma^{*}$, 18.VI16.VII.1986, 2-9.VII.1988, K. Aagaard (KA, ZMB) ; Hedmark, Storelvdal, Storbekken, Malaise trap, 1 \% , 26.VI.1988, K. Aagaard (KA).

Male imago ( $\mathrm{n}=8$ except when otherwise stated)

The male imago was described by Cranston \& Oliver $1988: 428$. Their description, however, should be extended concerning the wing chaetotaxy and the hypopygium.

Wing. VR 1.23-1.33,1.29. C extension 79-105,92 $\mu \mathrm{m}$ long. Brachiolum with 7-11 setae ; C extension with 9-20,14 non-marginal setae ; $\mathrm{Sc}$ with 21-48,35; $R$ with $39-69,55 ; R_{1}$ with 27-47,36; $\mathbf{R}_{4+5}$ with $37-81,59$; $\mathbf{R M}$ with $3-9,5$; $\mathbf{M}$ with 18-32,24; $\mathrm{M}_{1+2}$ with $60-80,67 ; \mathrm{M}_{3+4}$ with $37-51,45$; $\mathrm{Cu}$ with $30-49,38 ; \mathrm{Cu}_{1}$ with $18-27,24$; Pcu with $36-42,45$; and An with $31-48,35$ setae. Axillary sclerite with 5-6,6 setae. Wing membrane with setae covering most cells, with 33-75,54 setae in cell $\mathrm{m}$ basally of RM. Squama with $18-26,21$ setae ; longest seta $124-210,171 \mu \mathrm{m}$ (4) long ; shortest seta 38-83,56 $\mu \mathrm{m}$ (7) long.

Hypopygium (Fig. $6 \mathrm{D}, \mathrm{E}$ ). Anal point proper $0-15,3 \mu \mathrm{m}$ long (present in 2 out of 8 specimens); with $23-40,30$ setae at base on tergite IX ; laterosternite IX with 6-10,8 setae. Phallapodeme $79-109,93 \mu \mathrm{m}$ long; transverse sternapodeme $77-105,97 \mu \mathrm{m}$ long. Virga absent. Gonocoxite $210-236,227 \mu \mathrm{m}$ long ; inferior volsella low, usually with indication of apical swelling, ending at $0.73-0.79,0.76$ of gonocoxite length. Gonostylus 94-105,99 $\mu \mathrm{m}$ long ; crista dorsalis low ; megaseta
11-19,14 $\mu \mathrm{m}$ long. HR 2.19-2.39,2.27; HV 2.59-2.94,2.83.

\section{Remarks}

$M$. beringiensis may be no more than a small form of $M$. fuscipes differing in having strongly reduced or absent anal point and in slightly fewer setae on squama. The species was previously known only from the Yukon Territory in Canada.

\section{Metriocnemus picipes (Meigen) (Fig. 7 A-D)}

Chironomus picipes (Meigen), van der Wulp 1974 : 136 : Edwards 1929 : 311 ; Pinder $1978: 90$, Fig. 131 B.

Metriocnemus hirtipalpis Kieffer, 1915 : 478.

Metriocnemus longipalpus Sinharay et Chaudhuri, $1978: 281$, syn. n.

Chironomus paganicus Walker, 1856 : 183.

Type material : Lectotype $\sigma^{\prime}$, here designated, type locality (?Aachen) and date not given (MNHN). Paralectotypes : 2 , as holotype ; 1 o , as holotype, misidentified $=$ Rheocricotopus effusus (Walker) ; 1 o , 1 \&, as holotype, misidentified = Mitriocnemus atriclava Kieffer (MNHN).

Other material examined : China : Sichuan, Mt. Emy $1 \sigma^{\circ}, 18$. V.1986, X. Wang ; Jilin, Mt. Changbai 1 O , 7.VII.1986, X. Wang (XW). India : West Bengal, Tung, 1 ơ, 10.V.1973, S. Basak, paratype of Metriocnemus longipalpus (ZMB). Norway : Hedmark, Storelvdal, Atnaelv, Solbakken, Malaise Trap, 2 ơ, 17.VI \& 2.VIII.1986, K. Aagaard (KA, ZMB) ; Nord Trøndelag, Høylandet, Skiftesåa, 1 o , 11.VI.1986, K. Aagaard (KA).

Diagnostic characters : The low number of setae (less than 10) on each of subcosta and M, combined with a high AR (1.8(?)-2.9) and $L R_{3}$ (0.44-0.46), and a conspicuously long spur of the front tibia (2.0-2.4 times as long as apical width of tibia) will serve to distinguish the species from other members of the fuscipes group. The female has a relatively small gonocoxite with no apicomedian projection and 10-12 setae, sternite VIII does not form a floor under vagina, and the cercus is longer than the notum.

Male imago ( $n=6-7$ except when otherwise stated)

Total length 3.41-4.30,3.71 mm. Wing length $1.98-2.51,2.19 \mathrm{~mm}$. Total length/wing length 1.61-1.74,1.70. Wing length/length of profemur 
2.18-2.55,2.31. Coloration brownish black with brown halteres.

Head. AR 2.21-2.86,2.53. Ultimate flagellomere 709-784,756 $\mu \mathrm{m}$ long. Temporal setae 23-28,25 including 10-16,13 inner verticals ; 5-8,6 outer verticals ; and 5-9,6 postorbitals. Clypeus with $32-35,34$ setae. Tentorium 161-176,169 $\mu \mathrm{m}$ (4) long ; 45-53,48 $\mu \mathrm{m}$ (4) wide. Palp segments lengths (in $\mu \mathrm{m})$; $41-49,45$; $62-83,72$; $248-315,279$; $143-$ 236,$207 ; 191-255,217$. Third palpal segment with 2 median and 1 lateral apical lanceolate sensilla clavata.

Thorax. Antepronotum with 12-14,13 (5) setae. Dorsocentrals 47-74,58; acrostichals 28-38,32 (5) ; prealars 46-58,54 (5) ; supraalars 2-4,3 (5). Scutellum with $42-54,48$ setae.

Wing. VR 1.15-1.24,1.19. C extension 79-109,93 $\mu \mathrm{m}$ long. Brachiolum with 9-12,10 setae ; C extension with 11-22,13 non-marginal setae;
Sc with 0-7,2 ; $\mathrm{R}$ with $38-72,52$; $\mathrm{R}_{1}$ with $35-47,42$; $\mathrm{R}_{4+5}$ with 33-80,55; $\mathrm{RM}$ with 2-4,3; $\mathrm{M}$ with 3-11,6; $\mathbf{M}_{1+2}$ with 68-94,79; $\mathrm{M}_{3+4}$ with 33-60,48; $\mathrm{Cu}$ with $30-54,44$; $\mathrm{Cu}_{1}$ with $24-40,30$; Pcu with 18-60,42 ; and An with 42-55,49 setae. Wing membrane covered with setae ; with $15-65,39$ setae in cell $\mathrm{m}$ basally of RM. Axillary sclerite with 5-7 (3) setae. Squama with $42-58,51$ setae ; longest setae 274-300,283 $\mu \mathrm{m}$ (5) long ; shortest seta 49-83,68 $\mu \mathrm{m}$ long.

Legs. Spur of front tibia 90-120,106 $\mu \mathrm{m}$ long ; spurs of middle tibia $41-56,52 \mu \mathrm{m}$ and $39-53,49 \mu \mathrm{m}$ long. Width at apex of front and middle tibia 45-56,51 $\mu \mathrm{m}$; of hind tibia 58-75,67 $\mu \mathrm{m}$. Comb with 10-12,12 setae ; longest seta 60-75,67 $\mu \mathrm{m}$ long ; shortest seta 32-38,35 $\mu \mathrm{m}$ long. Tarsomeres 1 and 2 of middle and hind leg each with 2 pseudospurs ; $23-38,30 \mu \mathrm{m}$. long on $\mathrm{ta}_{2}$ of middle leg; $30-60,39 \mu \mathrm{m}$ long on other tarsomeres. Lengths (in $\mu \mathrm{m})$ and proportions of legs :

\begin{tabular}{cccccccccccc}
\hline & $\mathrm{fe}$ & $\mathrm{ti}$ & $\mathrm{ta}_{1}$ & $\mathrm{ta}_{2}$ & $\mathrm{ta}_{3}$ & $\mathrm{ta}_{4}$ & $\mathrm{ta}_{5}$ & $\mathrm{LR}$ & $\mathrm{BV}$ & $\mathrm{SV}$ & $\mathrm{BR}(\mathrm{n}=4)$ \\
\hline $\mathrm{p}_{1}$ & $860-1068,948$ & $1030-1285,1115$ & $624-860,690$ & $369-491,407$ & $227-312,255$ & $151-184,160$ & $85-109,97$ & $0,61-0.67,0.63$ & $2.77-3.17,2,86$ & $2.74-5.03,2.95$ & $3.1-5.3 .39$ \\
$\mathrm{p}_{2}$ & $936-1200,1004$ & $985-1247,1061$ & $397-539,434$ & $236-331,259$ & $161-208,182$ & $113-137,123$ & $80-104,92$ & $0.38-0.42,0.41$ & $3.70-3.95,3.83$ & $4.54-5.05,4.75$ & $3.3-4.1 .39$ \\
$\mathrm{p}_{3}$ & $1002-1276,1062$ & $1257-1663,1373$ & $570-728,628$ & $331-435,364$ & $246-312,270$ & $142-180,159$ & $95-113,104$ & $0.44-0.50,0.46$ & $3.22-3.51,3.44$ & $3.55-4.06,3.91$ & $5.0-8.8 .69$ \\
\hline
\end{tabular}

Hypopygium (Fig. 7 A). Anal point proper $19-38,38 \mu \mathrm{m}$ long; with $30-40,37$ setae at base on tergite IX ; laterosternite IX with 9-12,10 setae. Phallapodeme 109-120,114 $\mu \mathrm{m}$ long; transverse sternapodeme $86-113,103 \mu \mathrm{m}$ long. Virga absent. Gonocoxite 244-278,259 $\mu \mathrm{m}$ long ; inferior volsella low with apical swelling, ending at $0.75-0.78,0.77$ of gonocoxite length. Gonostylus 101-126,113 $\mu \mathrm{m}$ long; with low and long crista dorsalis ; megaseta 12-15,14 $\mu \mathrm{m}$ long. HR 2.16-2.45,2.28; $\mathrm{HV}$ 2.94-3.50,3.22.

Female imago ( $\mathrm{n}=2$ except when otherwise stated)

Total length $3.10-3.97 \mathrm{~mm}$. Wing length 1.78-2.97 mm. Total length/wing length 1.74-1.92. Wing length/length of profemur 2.39-2.58. Coloration as in male.

Head. Antenna lost. Temporal setae 38-59, including 22-37 inner verticals, 12 outer verticals, and
4-10 postorbitals. Clypeus with 28 setae. Tentorium 158-169 $\mu \mathrm{m}$ long, $21-23 \mu \mathrm{m}$ wide. Stipes $165-173 \mu \mathrm{m}$ long, 7.5-79 $\mu \mathrm{m}$ wide. Palp segments lengths (in $\mu \mathrm{m}): 41-45,56,158-165,163-169,244$ (1). Coronal suture absent.

Thorax. Antepronotum with 17-18 setae. Dorsocentrals 88-93, acrostichals 29 (1), prealars 45-50, supraalars 2 . Scutellum with 50-60 setae.

Wing. VR 1.18-1.22. C extension 105-113 $\mu \mathrm{m}$ long. Brachiolum with 8-11. C extension with 11-16 non-marginal setae, $\mathrm{R}$ with $49-65, \mathrm{R}_{1}$ with 57-60, $\mathrm{R}_{4+5}$ With 93-111, $\mathrm{RM}$ with 4-9, $\mathrm{M}$ with 13-27, $M_{1+2}$ with 61-69, $M_{3+4}$ with $45, \mathrm{Cu}$ with 29-47, $\mathrm{Cu}_{1}$ with $30-35$, Pcu with 58-80, and An with 39-54 setae. Wing membrane with setae covering most cells, with 51-110 setae in cell m basally of RM. Axillary sclerite with 5(1) setae. Squama with 27-28 setae.

Legs. Spur of front tibia 75-79 $\mu \mathrm{m}$ long, spurs of middle tibia $49 \mu \mathrm{m}$ and $45-40 \mu \mathrm{m}$ long, of hind 

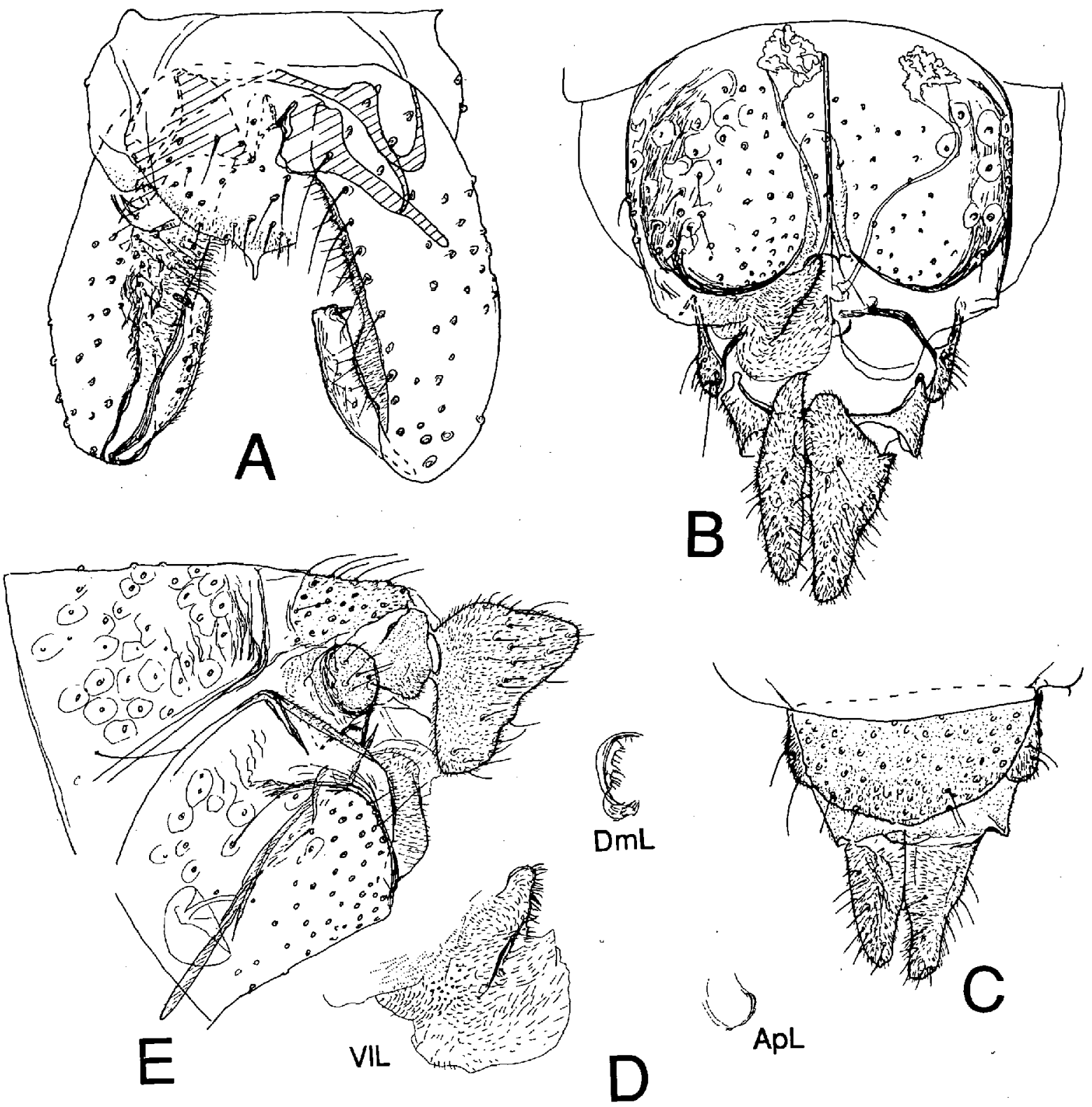

Fig. 7. Metriocnemus spp, imagines : A. M. picipes (Meigen), male hypopygium ; B-D, M. picipes, female genitalia, ventral view (B), dorsal view (C), and lobes of gonapophyses (D) ; E. M. atriclava Kieffer, female genitalia, lateral view. (DmL, dorsomesal lobe; VIL, ventrolateral lobe ; ApL, apodeme lobe).

Fig. 7. Metriocnemus spp., imagos : A. M. picipes (Meigen), hypopyge mâle ; B-D, M. picipes, genitalia femelle, vue ventrale (B), vue dorsale (C), et lobes de gonapophyses (D) ; E. M. atriclava Kieffer, genitalia femelle, vue latérale. (DmL, lobe dorsomésal ; VIL, lobe ventrolatéral ; ApL, lobe apodème). 
tibia 94-98 $\mu \mathrm{m}$ and $36 \mu \mathrm{m}$ (1) long. Width at apex of front and middle tibia $45-49 \mu \mathrm{m}$, of hind tibia 56-71 $\mu \mathrm{m}$. Comb of 11 setae, 23-60 $\mu \mathrm{m}$ long. Tarsomeres 1 and 2 of middle and hind leg each with
2 pseudospurs, $30-34 \mu \mathrm{m}$ long on ta 2 of middle leg, 34-49 $\mu \mathrm{m}$ long on other tarsomeres. Lengths (in $\mu \mathrm{m}$ ) and proportions of legs :

\begin{tabular}{cccccccccccc}
\hline & $\cdot \mathrm{fe}$ & $\mathrm{ti}$ & $\mathrm{ta}_{1}$ & \multicolumn{1}{c}{$\mathrm{ta}_{2}$} & \multicolumn{1}{c}{$\mathrm{ta}_{3}$} & \multicolumn{1}{c}{$\mathrm{ta}_{4}$} & \multicolumn{1}{c}{$\mathrm{ta}_{5}$} & \multicolumn{1}{c}{$\mathrm{LR}$} & $\mathrm{BV}$ & $\mathrm{SV}$ & $\mathrm{BR}$ \\
\hline $\mathrm{p}_{1}$ & $\mathbf{7 4 2 - 8 0 3}$ & $836-954$ & $558-591$ & $311-378$ & $217-236$ & $132-142$ & $85-99$ & $0.62-0.65$ & $2.75-2.78$ & $2.89-2.98$ & $1.6-2.6$ \\
$\mathrm{p}_{2}$ & $813-879$ & $860-964$ & $\mathbf{3 6 9 - 3 8 3}$ & $217-241$ & 170 & 113 & $85-90$ & $0.40-0.43$ & $3.48-3.62$ & $4.54-4.81$ & $2.4-2.5$ \\
$\mathrm{p}_{3}$ & $\mathbf{8 7 9 - 9 9 2}$ & $1143-1276$ & $558-624$ & $321-359$ & $255-284$ & $132-146$ & 95 & 0.49 & $3.21-3.27$ & $3.63-3.64$ & 2.9 \\
\hline
\end{tabular}

Genitalia (Fig. 7 B-D). Sternite VIII with 92-114 setae. Gonoxoxite IX relatively small, without apical projection, with 10-12 setae. Tergite IX rounded, undivided, with 48 setae. Cercus $206 \mu \mathrm{m}$ (1) long. Seminal capsule $49 \mu \mathrm{m}$ (1) long, $49-53 \mu \mathrm{m}$ wide. Notum 128-131 $\mu \mathrm{m}$ long.

\section{Remarks}

The Indian specimen is about 15 per cent longer than the largest European specimens and its antennal ratio is 2.21. (Sinharay and Chaudhuri gives 1.8). However, there appear to be no other differences except for a slightly higher chaetotaxy in the Indian specimen related to size. The Chinese specimens have a $\mathrm{LR}_{\mathbf{3}}$ of 0.50 , but are otherwise typical. The females are only tentatively associated. There are two species of females in the Meigen collection under the name $M$. picipes. The one described here conforms best with the male in the wing chaetotaxy.

The species previously was known from Greenland and widespread in Europe, but previous findings need reconfirmation, and $M$. wittei from Africa (see introduction) could be a synonym.

\section{Metriocnemus atriclava Kieffer (Fig. 7 E)}

Metriocnemus atriclava Kieffer, 1921: 83 ; Sæther 1989a : 427.

Metriocnemus atriclava var. rivicola Kieffer, $1925: 563$.

Metriocnemus atriclava Kieffer ; Edwards 1939 : 311, Pinder 1978 : 90, fig. 13D.

Nomenclatorial note : Sæther (1989a : 427) regarded the synonymy of $M$, atriclava Kieffer with $M$. atriclava sensu Edwards as questionable, suggesting that latter might be a synonym of the $M$. picipes. The present material shows that this is clearly not the case and as the type material of Kieffer probably is lost, $M$. atriclava in the sense of Edwards should be regarded as the valid species.

New material examined : The Meigen collection, no locality (?Aachen) and no date, $1 \circ, 1 \%$, misidentified paralectotypes of $M$. picipes (see above) (NNHN).

Although the hypopygium and the hind legs are missing the male imago fits very closely with the description in Sæther (1989a : 427). The wing chaetotaxy are slightly, but not significantly, higher, with 39 setae on subcosta, 29 on $M$ and 110 setae in cell m basally of RM.

Diagnostic characters for the female imago : The female can be separated from other described species by having 4 flagellomeres, a relatively small gonocoxite without apical projection and with numerous (about 24) setae, and cercus apparently slightly shorter than notum.

Female imago $(\mathrm{n}=1$, tentatively associated)

Length $3.76 \mathrm{~mm}$. Wing length $2.04 \mathrm{~mm}$. Total lenght/wing length 1.84 . Wing length/length of profemur 2.27. Coloration blackish brown, with slightly darker markings and posterior third of scutellum slightly more pale. Haltere brown.

Head. AR. 0.24. Lengths (in $\mu \mathrm{m}$ ) of flagellomeres : $135,83,116,79$. Longest sensilla chaetica $73 \mu \mathrm{m}$ long. Temporal setae 62 , including 42 inner verticals, 15 outer verticals, and 5 postorbitals. Clypeus with 43 setae. Tentorium $165 \mu \mathrm{m}$ long, $21 \mu \mathrm{m}$ wide. Stipes $191 \mu \mathrm{m}$ long, $79 \mu \mathrm{m}$ wide. Palp segments lengths (in $\mu \mathrm{m}$ ) : 45, 60, 203, 199, 257. Coronal suture reduced, $28 \mu \mathrm{m}$ long. 
Thorax. Antepronotum with 25 setae. Dorsocentrals 127 , acrostichals 45 , prealars 31 , supraalars 4 . Scutellum with 56 setae.

Wing. VR 1.21. C. extension $98 \mu \mathrm{m}$ long. Brachiolum with 12 setae. C. extension with 26 nonmarginal setae, $S c$ with $55, R$ with $74, R_{1}$ with 80 , $\mathbf{R}_{4+5}$ with $105, \mathbf{R M}$ with $7, \mathbf{M}$ with $33, \mathrm{M}_{1+2}$ with about $140, \mathrm{M}_{3+4}$ with $63, \mathrm{Cu}$ with $45, \mathrm{Cu}_{1}$ with 45 , Pcu with about 105, and An with 63 setae. Wing membrane covered with setae, with about 135 setae in cell $\mathrm{m}$ basally of RM. Squama with at least 22 setae.

Legs. Spurs, tibia width, combs and pseudospurs as in male. Tarsi of front and middle legs lost. Front femur $898 \mu \mathrm{m}$, front tibia $1058 \mu \mathrm{m}$, middle femur $992 \mu \mathrm{m}$, middle tibia $1058 \mu \mathrm{m}$ long. Lengths (in $\mu \mathrm{m})$ and proportions of hind leg :

\begin{tabular}{ccccccccccc}
\hline $\mathrm{fe}$ & $\mathrm{ti}$ & $\mathrm{ta}_{1}$ & $\mathrm{ta}_{2}$ & $\mathrm{ta}_{3}$ & $\mathrm{ta}_{4}$ & $\mathrm{ta}_{5}$ & $\mathrm{LR}$ & $\mathrm{BV}$ & $\mathrm{SV}$ & $\mathrm{BR}$ \\
\hline 1106 & 1503 & 624 & 359 & 284 & 161 & 104 & 0.42 & 3.56 & 4.18 & 3.7 \\
\hline
\end{tabular}

Genitalia (Fig. 7 E). Sternite VIII with about 120 setae. Gonocoxite relatively small without projection, with 24 setae. Tergite IX undivided, with 48 setae. Cercus $184 \mu \mathrm{m}$ long. Seminal capsule $64 \mu \mathrm{m}$ long, $53 \mu \mathrm{m}$ wide. Notum apparently $199 \mu \mathrm{m}$ long. (Caudal end obscured since lateral view).

\section{Remarks}

The female may well belong to another species. However, it does not fit any of the other described species and even if the male is lacking the hypopygium its identity appears relatively certain.

M. atriclava is known from Germany, Great Britain, Ireland and Norway.

\section{Acknowledgements}

I am much indebted to K. Aagaard, Norwegian Institute for Nature Research, Trondheim, Norway ; P.K. Chaudhuri, University of Burdwan, Burdwan, India ; L. Matile, Museum National d'Histoire Naturelle, Paris ; E. Nartshuk, Zoological Museum, St. Petersburg ; D.R. Oliver, Biosystematic Research Centre, Ottawa ; and X. Wang, Nankai University, Tianjin, China ; for placing the necessary type and other material at my disposal ; and to $\varnothing$ A. Schnell and G.A. Halvorsen, Institute of Zoology, University of Bergen, for marking some slide preparations.

\section{References}

Ashe P. \& Cranston P.S. 1990. - Family Chironomidae. Pp. 113-335 in Soos A. \& Papp L. (eds) : Catalogue of Palaearctic Diptera. 2. Psychodidae-Chironomidae. 499 pp, Budapest.

Chaudhuri P.K., Bhattacharyay S. \& Dutta T. 1989. - Adults of orthocladiid midges of Metriocnemus group (Diptera : Chironomidae) from India. Oriental insects, $23: 307-327$.
Coffman W.P., Cranston P.S., Oliver D.R. \& Sæther O.A. 1986. - The pupae of Orthocladiinae (Diptera : Chironomidae) of the Holarctic region - Keys and Diagnoses. Ent. scand.; Suppl. 19 : 147-296.

Cranston P.S. \& Judd D.D. 1987. - Metriocnemus (Diptera : Chironomidae). An ecological survey and description of a new species. $J I N$. Y. ent. Soc. 95 : 534-546.

Cranston P.S. \& Oliver D.R. 1988, - Additions and corrections to the Nearctic Orthocladiinae (Diptera : Chironomidae). Can. Ent. $120: 425-462$.

Cranston P.S., Oliver D.R. \& Sæther O.A. 1983. - 9. The larvae of Orthocladiinae (Diptera : Chironomidae) of the Holarctic region - Keys and diagnoses. Ent. scand., Suppl. $19: 149-291$.

Edwards F.W. 1929. - British non-biting midges (Diptera, Chironomidae). Trans. $R$. ent. Soc. Lond. $77: 279-430$.

Edwards F.W. 1931. - Diptera of Patagonia and South Chile. II. 5, Chironomidae: 233-331, British Museum, London.

Freeman P. 1956. - A study of the Chironomidae (Diptera) of Africa south of the Sahara, Part II. Bull. Br. Mus. nat. Hist. (Ent.) $4: 287-368$.

Goetghebuer M. 1940-50. - 13 g. Tendipedidae Orthocladiinae. A. Die Imagines. Fliegen pal. Reg. 3 (1) : 1-208.

Holmgren A.E. 1869. - Bidrag til Kännedomen om Beeren Eilands och Spetsbergens insekt-fauna. $K$. svenska Vetensk.Akad. Handl. (n.s.) 8(5) : 1-55.

Holmgren A.E. 1883. - Diptera p. 162-180 in Holmgren \& Aurivillius : Insecta a viris doctissimis Nordenskiöld illum ducem sequentibus in insulis Waigatsch et Novaja Semilia anno 1875 collecta.-Ent. Tidskr. $4: 139-194$.

Johannsen O.A. 1932. - Orthocladiinae of the Malayan subregion of the Dutch East Indies. Arch. Hydrobiol. Suppl. 9 : 725-732.

Kieffer J.J. 1899. - Description d'un nouveau genre et tableau des genres européens de la famille des Chironomides (Dipt.). Bull. Soc. ent. Fr. $4: 66-70$.

Kieffer J.J. 1915. - Neue halophile Chironomiden. Arch. Hydrobiol. Suppl. 2 : 472-482.

Kieffer J.J. 1918. - Chironomides d'Afrique et Asie conservés au Musée National Hongrois de Budapest. Annls hist.-nat. Mus. nath hung. $16: 31-136$. 
Kieffer J.J. 1921. - Chironomides nouveaux ou peu connus de la région paléarctique. Bull. Soc. Hist. nat. Metz, 29 : 51-109.

Kieffer J.J. 1925. - Deux genres nouveaux et plusieurs espèces nouvelles du groupe des Orthocladiariae (Diptères, Chironomides). Annls Soc. scient. Brux., 44 : 555-556.

Kieffer J.J. \& Thienemann A. 1919. - Chironomiden gesammelt von Dr. A. Koch (Münster in W.) auf den Lofoten, der Bäreninsel und Spitzbergen (Dipt.). Ent. Mitt., $8: 38-48$, 110-124.

Lundström C. 1915. - Diptera Nematocera aus den arctischen Gegenden Siberien. Zap. imp. Akad. Nauk. 29 : 1-33.

Meigen J.W. 1818. - Systematische Beschreibung der Bekannten europäischen zweiflügeligen Insekten. I. xxxvi +333 p., 11 pls. Aachen.

Oliver D.R., Dillon M.E. \& Cranston P.S. 1990. $-A$ catalog of Nearctic Chironomidae. Res. Branch Agric. Can., Publ. 1857/B, $89 \mathrm{p}$.

Pinder L.C.V. 1978. - A key to adult males of British Chironomidae. Part 1. The key; Part 2. Illustrations of the hypopygia. Scient. Publ. Freshw. biol. Ass. 37, 169 pp. ; 189 figs.

Sæether O.A. 1969. - Some Nearctic Podonominae, Diamesinae, and Orthocladiinae (Diptera : Chironomidae). Bull. Fish. Res. Bd Can, 170.154 p.

Sæther O.A. 1977. - Female genitalia in Chironomidae and other Nematocera : morphology, phylogenies, keys. Ibid. 197, 209 p.

Sather O.A. 1980. - A glossary of chironomid morphology terminology (Chironomidae : Diptera). Ent. scand., Suppl..15, $51 \mathrm{p}$.

Sæther O.A. 1986 . - On the systematic positions of Dolichoprymna, Amblycladius, and Kloosia (Diptera : Chironomidae). Abs. First int. Congr. Dipterol. : 215.

Sæther O.A. 1989a. - Metriocnemus van der Wulp : a new species and a revision of species described by Meigen, Zetterstedt, Stæger, Holmgren, Lundström and Strenzke (Diptera : Chironomidae). Ent. scand. $19: 393-430$.

Sæther O.A. 1989b. - Phylogenetic trends and their evaluation in chironomids with special reference to orthoclads. Acta Biol. Debr, oecol. hung. 2 : 53-75.

Sæther O.A. \& Sublette J.E. 1983. - A review of the genera Doithrix n. gen., Georthocladius Strenzke, Parachaetocladius Wülker, and Pseudorthocladius Goetghebuer (Diptera : Chironomidae, Orthocladiinae). Ent. scand., Suppl. 20, $100 \mathrm{p}$.
Sæther O.A., Sublette J.E. \& Willassen E. 1984. - Chironomidae (Diptera) from the 2nd. Fram Expedition (1898-1902) to Arctic North America described by J.J. Kieffer. Ent. scand. $15: 249-275$.

Sasa M. 1983. - Studies on chironomid midges of the Tana River. Part 6. Description of species of the subfamily Orthocladiinae recovered from the main stream in the July survey. Res. Rep. natn. Inst. environ. Stud. $29: 68-97$.

Sasa M. 1989. - Studies on the chironomid midges (Diptera, Chironomidae) of Shou River. Res. Rep. Toyama Prefect. Envir. Poll. Res. Center 1989 : 27-44, 83-84, 87-95.

Sasa M. 1990. - Studies on the chironomid midges (Diptera : Chironomidae) of the Nansei Islands, Southern Japan, Japan. J. Exp. Med. 60 : 111-165.

Sasa M. 1991. - Studies on the chironomid of some rivers and lakes in Japan. Part 2. Studies on the chironomids of the Lake Towada area, Aomori. Res. Rep. Toyama Prefect. Envir. Poll. Res. Center 1991 : 68-81, 135-141.

Sasa M. \& Hasegawa H. 1988. - Additional records of the chironomid midges from the Ryukyu Islands, southern Japan. Jap. J. sanit. Zool., $39: 229-256$.

Sasa M. \& Okazawa T. 1992. - Studies on the chironomid meidges (yusurika) of Toga Mura, Toyama. Part 2. The subfamily Orthocladiinae. - Res. Rep. Toyama Prefect. Envir. Poll. Res. Center 1992 : 92-230.

Sinharay D.C. \& Chaudhuri P.S. 1978. - A study of Orthocladiinae of India. Part III. Genus Metriocnemus van der Wulp. Spixiana 1 : 281-286.

Sublette J.E. 1966. - Type specimens of Chironomidae. (Diptera) in the U.S. National Museum. J. Kans. ent. Soc. 39 : 580-607.

Sublette J.E. 1967. - Type specimens of Chironomidae (Diptera) in the Cornell University Collection. Ibid. $40: 477-564$.

Sublette J.E. \& Sasa M. 1994. - Chironomidae collected in Onchocerciasis endemic areas of Guatemala (Insecta, Diptera). Spixiana, Suppl. $20: 1-60$.

Sublette J.E. \& Sublette M.S. 1965. - Family Chironomidae (Tendipedidae), pp. 142-181 in Stone A., Sabrosky C.W., Wirth W.W., Foote R.H. \& Coulson J.R. (eds) : A catalogue of the Diptera of America north of Mexico. U.S. Dep. agric. Handb. 276, $169 \mathrm{p}$.

Walker F. 1856. - Insecta britannica, Diptera 3. xxiv + 352 p. London.

Wulp F.M. van der 1874. - Dipterologische aanteekeningen. Tijdschr. Ent. 17 : 109-148. 